\title{
Regional Growth and SMEs in Brazil: a Spatial Panel Approach
}

Tulio A. Cravo

tulio.cravo@pucrs.br, Pontifícia Universidade Católica do Rio Grande do Sul, Porto

Alegre/RS, Brazil

Bettina Becker

b.becker@aston.ac.uk, Aston Business School, Aston University, Birmingham, B4 7ET, UK

Adrian Gourlay

A.R.Gourlay@lboro.ac.uk, Loughborough University, Leicestershire, UK, LE11 3TU

Abstract

This paper examines economic growth for a panel of 508 Brazilian micro-regions for the period 1980-2004, using spatial econometrics and paying particular attention to the importance of small and medium-size enterprises (SMEs). The findings indicate the presence of spatial dependence in the process of economic growth and the existence of two spatial regimes in Brazil. Human capital level of the whole population is an important growth determinant, but does not generate positive spillovers. Furthermore, human capital embodied in SMEs is more important than the size of this sector for regional growth but does not generate positive spatial spillovers either.

Keywords: Firm size, market structure, regional economic growth, spatial panel econometrics, entrepreneurship.

JEL Classification: O10, L11, R11, C31. 


\section{Introduction}

In recent years, a growing interest in the importance of small and medium-sized enterprises (SMEs) for economic growth has been observed in the literature, largely because this sector is responsible for the majority of employment generation in developed as well as in developing countries (AYYAGARI et al., 2007). This explains the large amount of financial resources allocated to the development of the SME sector. For instance, the World Bank devoted US\$ 9.8 billion to SME projects during the period 2006-2012 (IEG, 2013). ${ }^{1}$ A seminal study using a cross-section of countries to analyse SMEs and growth was provided by BECK et al. (2005), and the literature provides recent examples of papers using this approach to study the relationship between SMEs, entrepreneurship and growth. ${ }^{2}$ Van STEL et al. (2005) and WENNEKERS et al. (2005) provide cross-country evidence that suggests a positive impact of entrepreneurship on growth for developed countries and the converse result for developing ones. Individual-country studies support this dichotomy in the results for developed versus developing countries (e.g. Audretsch and KeIlbaCH, 2004; Mueller, 2007; Cravo 2010; CRAvo et al, 2012). ${ }^{3}$ The available empirical evidence thus suggests that while studies that focus on developed nations suggest a positive impact of SMEs and entrepreneurship on economic growth, studies examining developing countries suggest a negative impact.

Nevertheless, the literature that analyses the relationship between regional economic growth and SMEs has been neglecting the spatial dependence. There is a paucity of studies exploring spatial spillovers in this relationship and limited evidence, especially for developing countries. Econometrically, the omission of spatial dependence and spillovers in growth regressions produces biased results, as argued by REY and MONTOURI (1999), and requires spatial econometrics to be estimated correctly. The importance of spatial spillovers when analysing economic growth is extensively documented in theoretical and empirical papers 
(e.g. ERTUR and Koch, 2007; Arbia et al., 2008; MoHL and Hagen, 2010). Conceptually, the recent literature also has increasingly argued in favour of considering spatial dependence and spillovers in the analysis of the relationship between SMEs and economic growth. ${ }^{4}$

Spatial spillovers could, for instance, take the form of 'externalities' such as culture: A set of values, cultural traditions and habits that drive entrepreneurship capital are exchanged locally and across the (artificial) administrative borders of regions and hence may impact growth. Alternatively, spillovers could take the form of collective purposive actions such as developing common infrastructure. The latter requires coordinated regional policies, hence consideration of spatial dependence in SME research may inform policy design. More specifically, PiJnEnburg and KHOLODILIN (2012) consider that the spatial dimension of the presence of SMEs and entrepreneurship may affect growth in three ways, through increased competition from neighbouring regions, through the importance of these regions' entrepreneurship capital in an entrepreneur's decision of where to set up a new firm, and through the spatial clusters into which innovative entrepreneurial activity that affects growth tends to evolve. OLENJNIK (2008) and AUDRETSCH et al. (2010) consider that human capital spillovers may also flow beyond regions, one mechanism of which could be migration. Similarly, and related to the theory of innovative entrepreneurship (e.g. ACs et al., 2009), human capital within SMEs may impact growth in a neighbouring region through, for instance, cost-motivated migration of innovative high-skilled entrepreneurs who will set up their own firm in order to pursue and commercialise their innovation: The knowledge generated in the region of origin will then contribute to economic growth in the neighbouring region. Summarizing, there are thus two types of spatial spillovers related to SMEs we attain to estimate: the size of the SME sector and the human capital of the SME sector. ${ }^{5}$

Therefore, the aim of this paper is to address this gap in the literature by providing an analysis of the importance of the SME,s sector for regional economic growth in Brazil as a 
developing country for a panel of micro-regions from 1985 to 2004, considering the spatial dependence. ${ }^{6}$ The paper provides an extended analysis of the relationship between SMEs and economic growth by considering spatial spillovers. This can be considered an extension of BECK et al. (2005) who use similar strategy without considering spatial dependence. This research provides for the first time empirical evidence on the importance of space for the regional economic growth process in Brazil using spatial panel econometrics estimators suggested by ELHORST (2010a). Existing evidence on Brazil that recognises the importance of spatial spillovers for the process of economic growth uses cross-section data and hence a different estimator (e.g. SiLveira-Neto and AzZOni, 2006; Resende, 2011). Besides, this paper investigates how different aspects of the SME sector (size and human capital) influence economic growth in different spatial regimes. These have also not been considered in existing evidence.

The remainder of the paper is organized as follows. The second section discusses the literature of SMEs and economic growth, and the mechanisms through which SMEs might impact economic performance. Section three presents the baseline model and its extensions to consider spatial dependencies. Section four describes the data, spatial weights and the initial analysis of the spatial dependence. Section five presents the results, and section six concludes.

\section{SMEs and Economic Growth}

It has long been recognised that entrepreneurship is an important factor to economic growth. BAUMOL (1968) considers entrepreneurs the key factor to stimulate economic growth and suggests that innovations require entrepreneurial initiative to be introduced. Furthermore, he considers that if we seek to explain the success of economies which have managed to grow significantly with those that have remained relatively stagnant, we find it difficult to do so 
without taking into consideration differences in the availability of entrepreneurial talent and in the motivational mechanism which drives them on. Nevertheless, only recently the literature that links entrepreneurship and SMEs to economic growth has gained importance.

BECK et al. (2005) estimate the standard growth regression including the relative size of the SME sector in terms of employment and find a positive but not robust impact of this sector on economic growth for a cross-section of countries. The study does not discuss in detail the mechanism through which SMEs might affect growth but suggests that the proSME policy view is based on the arguments that the SME sector brings social benefits that stem from greater competition. This is in line with FRITSCH and MUELLER (2004) who also argue that entrepreneurship results in a more intense competition.

SME and entrepreneurship might also impact economic growth because they are considered the link between knowledge creation and knowledge commercialisation. ACs et al. (2009) suggest that entrepreneurship contributes to economic growth by acting as a conduit through which knowledge created within incumbent firms spills over to agents who set up new firms. The innovator employee of the incumbent firm, who generates the new knowledge or idea, will weigh the alternative of starting a new firm, if the expected return from commercializing the idea is sufficiently different for the innovator and for the incumbent decision-making firm, such that the firm does not consider it worthwhile to pursue and commercialise the idea. In this case, the new knowledge or idea would remain dormant in the incumbent firm and would not be able to contribute to economic growth. If the cost of starting a new firm is sufficiently low, the employee may choose to leave the incumbent firm to start a new firm and commercialise the idea. Acs et al. (2009) provide empirical results that are in line with this argument and suggest that in OECD countries, entrepreneurship might be a conduit for facilitating such spillover of knowledge and thus impact economic growth via this channel. Empirical results for the US provided by ACS and ARMINGTON (2004) also support 
the argument that entrepreneurship is an important mechanism through which knowledge spillover contributes to economic growth. In addition, SoLOW (2007) recognizes entrepreneurship as one important force that drives a wedge between knowledge and total factor productivity, and argues that the study of entrepreneurship and small firms could add to the explanatory power of growth theory.

Bringing together the above two mechanisms through which entrepreneurship may contribute to economic growth, PiJnEnBURG and KHOLODILIN (2012) further argue that improvements in competition alongside the knowledge spillover characteristic make entrepreneurship an important factor in improving economic performance. Moreover, these authors present three arguments for including the spatial dimension of entrepreneurship in the analysis. Firstly, the spatial dimension of entrepreneurship increases competition because of a higher number of firm entries, as competitors can also be found outside a given region. Secondly, the entrepreneur's decision on where to set up a new firm depends not only on the entrepreneurship capital of that region, but also on entrepreneurship capital in neighbouring regions where the knowledge source might be located. Thirdly, regions with high innovative activity, linked to knowledge-based entrepreneurial activities, tend to cluster spatially. ${ }^{7}$ PiJnenburG and KhOlOdilin (2012)'s empirical results for Germany support these arguments as regions with more entrepreneurial neighbours have better economic performance. Similarly, BRUCE et al. (2009) present results suggesting that more small business activities in bordering states might increase a state's own economic growth in the U.S: The presence of more small businesses in neighbouring states has a positive impact on gross state product growth. This result is consistent with the view that more small firms might affect economic performance by reinforcing competition.

AUDRETSCH and KEILBACH (2007) also argue that the presence of entrepreneurial activities in neighbouring economies might be one channel through which entrepreneurship 
affects economic performance. The authors provide evidence that an increase in entrepreneurial activity in adjacent regions increases entrepreneurship in a given region in Germany. The results were considered by the authors as evidence in favour of the hypothesis that a set of values, cultural traditions and habits that drive entrepreneurship capital are exchanged locally and across the (artificial) administrative borders of the regions. ${ }^{8}$ It is important to note that the externalities captured in PIJNENBURG and KHOLODILIN (2012), AUdRETSCH and KEILBACH (2007) and BRUCE et al. (2009), and that will be analysed in this paper, stem from the SME sector itself and differ from the more specific spillovers generated from joint actions in clusters of SMEs that can generate efficiency gains that would otherwise be difficult to be captured by small firms (e.g. ScHMiTZ, 1995).

SMEs and entrepreneurship might also affect growth through human capital. The rate of increase in the technology level is an increasing function of education, and a higher level of education tends to induce the adoption of innovations earlier (e.g. NELSON and PHELPS, 1966). Besides, human capital can also encourage growth by stimulating the process of innovation. GRIFFITH et al. (2004) argue that R\&D has two faces and stimulates growth directly through innovation and indirectly through facilitating the imitation process. In the context of entrepreneurship, QIAN and ACS (2013) and QIAN et al. (2012) similarly argue that human capital is the key determinant of entrepreneurial absorptive capacity, which allows entrepreneurs to understand new knowledge, recognize its value and commercialize it in a firm, and which hence allows for the new knowledge to affect economic growth. The key finding of this model is the positive and highly significant effect of human capital on entrepreneurship, providing evidence for the important role of entrepreneurial absorptive capacity in facilitating entrepreneurial activity. ${ }^{9}$ Thus, it is reasonable to assume that human capital in SMEs is important for the absorptive capacity of this sector. If the SME sector 
improves its productivity, through innovation or imitation, a positive effect on growth is expected from the SMEs' human capital.

Human capital of neighbouring regions can also influence economic dynamics. AUDRETSCH et al. (2010), for instance, argue that the spatial dimension of human capital should be included in the analysis, as spillovers stemming from human capital might go beyond the borders of the regions. OLEJNIK (2008) suggests that the level of human capital in neighbouring regions may have a negative effect on the level of per capita income in a given region, because an increase in the level of human capital in the neighbouring region is caused mainly by migration of the educated population away from adjacent regions. This reduces the human capital in these adjacent regions and hence, ceteris paribus, economic growth. This is in accordance with the argument linked to New Economic Geography models, whereby more skilled labour is an important factor that constitutes a centripetal force towards geographical concentration (e.g. KRUGMAN, 1999). The human capital within SMEs may also have a spatial dimension through which it affects growth in a neighbouring region. For instance, with respect to the innovative entrepreneurship argument discussed above, if the cost of setting up the new firm is sufficiently lower in a neighbouring region relative to the expected return from commercializing the idea, the high-skilled innovator may migrate. The knowledge generated in the region of origin will then contribute to economic growth in the neighbouring region. Conversely, OLEJNIK's (2008) argument of a negative spatial effect from overall human capital may also be applied to the human capital of the SME sector.

Importantly, there are some factors that might prevent SMEs from contributing to economic growth through the mechanisms described above. As noted in the previous section, empirical evidence suggests a positive impact of entrepreneurship on growth for developed countries and the converse result for developing ones. The different impact that SMEs and entrepreneurship have on countries at different stages of development might be related with 
institutional constraints. BECK et al. (2005) suggest that financial constraints impede SMEs' development. ACS et al. (2008) have attributed these differences in empirical results to different entrepreneurship responses to institutions. Similarly, BAUMOL (1990) suggests that while the total supply of entrepreneurs differs across economies, the productive contribution of the society's entrepreneurial activities varies much more because of their allocation between productive and unproductive activities due to differences in the institutional quality. $^{10}$

Thus, due to institutional differences the presence of SMEs in a developing economy does not have the influence on economic performance as in a developed one. VAN STEL et al. (2005), WENNEKERS et al. (2005) and ACs et al. (2008) provide empirical evidence indicating a U-shaped relationship between entrepreneurship and the level of development: At low levels of economic development, entrepreneurship and growth are negatively related, while at high levels of economic development, they are positively related. These papers show that this pattern might be influenced by the fact that the SME sector in developing countries typically is dominated by labour-intensive and low-tech firms that are more likely to be related with necessity entrepreneurship and, therefore, with lower growth expectations, lower human capital and smaller firm size (PosCHKE, 2013). ${ }^{11}$ Dominance of necessity entrepreneurship may thus hold those firms back from reaching their full potential and from contributing positively to economic growth. Necessity entrepreneurship is defined as the act of starting a business as the last resort of income generation. In contrast, opportunity entrepreneurship expresses the alternative motivation for starting a business, which is to exploit a perceived business opportunity. As illustrated by ACS et al. 2008, the ratio of opportunity to necessity entrepreneurship is greater in developed countries and this is shown to contribute to the explanation of why the relationship between entrepreneurship and economic development is most likely negative in low-income countries, while most likely being positive in high-income 
countries. In the context of Latin America, ACS and AMORós (2008) provide evidence that a high proportion of the entrepreneurial activity in the region is driven by necessity entrepreneurship. ${ }^{12}$ Hence, differences in the level of institutional development provide different incentives for productive entrepreneurship and we do not know whether the effect of SMEs on growth comes from the structure itself or from another factor related to SMEs, such as the level of human capital. ${ }^{13}$

Institutions also influence human capital formation for productive entrepreneurs. For instance, DIAS and MCDERMOTT (2006) propose a model where structural changes towards a modern economy depend on the role of entrepreneurs, human capital and institutions. In their model, entrepreneurs come from a pool of individuals that belong to the managerial class, which is specialized in two activities, rent-seeking and productive entrepreneurship. The authors argue that more productive entrepreneurs lead to more human capital formation by providing incentives for workers to seek education that suits a more highly skilled productive job offered by the entrepreneurs. Therefore, institutional barriers that prevent the development of productive entrepreneurship should be removed to provide incentives for human capital formation, generate more productive entrepreneurs and improve economic performance. If rent-seeking entrepreneurship dominates, educational improvement might also be neutralised and will have little long-run effect.

\section{The Baseline Model}

The baseline specification stems from the neoclassical growth model based on SoLOW (1956) and MANKIW et al. (1992), that considers physical and human capital as the main variables conditioning the growth process. However, TEMPLE (1999) argues that the most common approach is the ad hoc regression that encompasses other factors that influence growth as in 
BARRO's (1991) seminal work. In this approach, variables are chosen based on previous results in the literature rather than on an explicit theoretical model. In this context, LEVINE and RENELT (1992) listed an extensive number of variables included in growth regressions, and SALA-I-MARTIN (2002) argues that the growth literature that follows this tradition has exerted influence on other economic literatures such as development economics, economic geography, macroeconomics and econometrics. Recently, this influence has also been extended to study the importance of SMEs and entrepreneurship for economic growth (e.g. BeCK et al., 2005; Audretsch and KeILbaCH, 2004; Mueller, 2007). Hence, the baseline specification used in this study takes the following form:

$$
g r_{i t}=-\beta \ln y_{i, t-1}+\psi \ln X_{i t}+\phi \ln S M E R_{i t}+\gamma \ln S M E H_{i t}+\alpha_{i}+\mu_{t}+v_{i t}
$$

where $g r$ denotes the annual GDP per capita growth, $\ln y_{t-1}$ is the initial GDP per capita, $\beta$ the convergence coefficient, $i$ denotes each individual region, $t$ represents each period of time considered and $v_{i t}$ is the error term $\sim N\left(0, \sigma^{2}\right)$. The vector $X$ represents a set of control variables that encompasses growth determinants suggested by the Solow model as well as growth determinants that come from outside this model. The variables included in this vector are the overall level of human capital and population growth. As discussed in the previous section, researchers argue that SMEs and entrepreneurship are important growth determinants, thus, the additional feature of the specification is the inclusion of the relative size of the SME sector (SMER) as in BECK et al. (2005) and the human capital embodied in this sector (SMEH) to extend their model as in CRAvo et al. (2012). However, Equation (1) ignores the existence of spatial dependence in the regional growth process and instead assumes that regional observations are independent, and this results in major model misspecification (REY and MONTOURI, 1999). 
There are various ways of incorporating the spatial dependence in Equation (1). The most common specifications in spatial econometrics according to LESAGE and PACE (2009) are the spatial error model (SEM), the spatial autoregressive model (SAR) and the spatial Durbin model (SDM).

The SEM specification reflects spatial dependence working through the error terms and the baseline Equation (1) becomes:

$$
\begin{aligned}
& g r_{i t}=-\beta \ln \left(y_{i, t-1}\right)+\psi \ln X_{i t}+\alpha_{i}+\mu_{t}+\varepsilon_{i t} \\
& \varepsilon_{i t}=\lambda \sum_{j=1}^{N} w_{i j} \varepsilon_{j t}+v_{i t}
\end{aligned}
$$

where the variables are defined as in Equation (1), but hereafter to simplify the notation, $S M E R$ and $S M E H$ are also included in the vector $X$. The term $\varepsilon$ is the error term, where $w_{i j}$ contains information about the spatial structure and connectivity between regions $i$ and $j$. The term $\lambda$ is a scalar spatial error coefficient, and $v \sim N\left(0, \sigma^{2} I_{n}\right)$. A random shock introduced into a specific region affects the growth rate in that region and through the spatial transformation in the error term also impacts growth rates of other regions (REY and MONTOURI, 1999; ERTUR et al., 2006).

An alternative way of considering the spatial dependence is through the SAR specification, where the spatial lagged values of the dependent variable are included in the model as follows:

$$
g r_{i t}=\rho \sum_{j=1}^{N} w_{i j} g r_{j t}-\beta \ln \left(y_{i, t-1}\right)+\psi \ln X_{i t}+\alpha_{i}+\mu_{t}+v_{i t}
$$


where $\rho$ is the spatial autoregressive parameter and all other terms are defined as in Equation 2. As argued in ARBIA et al. (2008), the spatially lagged dependent variable incorporates a sort of spatial conditional convergence, where convergence is conditioned by the spatial structure. ${ }^{14}$ LESAGE and PACE (2009) argue that this specification is a hallmark of spatial econometrics and can be extended into the SDM specification that has the advantage of allowing for spatial effects working through the dependent variable, the initial income variable, and a set of conditioning variables. The unconstrained SDM takes the following form:

$$
g r_{i t}=\rho \sum_{j=1}^{N} w_{i j} g r_{j t}-\beta_{1} \ln \left(y_{i, t-1}\right)+\beta_{2} \sum_{j=1}^{N} w_{i j} \ln \left(y_{j, t-1}\right)+\psi_{1} \ln X_{i t}+\psi_{2} \sum_{j=1}^{N} w_{i j} \ln X_{j t}+\alpha_{i}+v_{i t}
$$

where everything is defined as in Equation (3), with the inclusion of the vectors $W \ln X_{j t}$ and $W \ln \left(y_{t-1}\right)$ used to account for the spatially lagged values of all conditioning variables.

This is an attractive specification because if $\psi_{2}=0$ and $\beta_{2}=0$ it becomes the SAR model, and if $-\rho \psi_{1}=\psi_{2}$ and $-\rho \beta_{1}=\beta_{2}$ the model is reduced to the SEM model. LESAGE and Fisher (2008), LeSAgE and PACE (2009) and ElHORST (2010b) provide a detailed discussion about the motivations and advantages of the SDM specification for growth models from a statistical point of view. They show that the use of an SDM specification rests on the plausibility of two circumstances that are likely to arise in applied regional spatial growth regressions: the spatial dependence in the disturbances of an OLS regression, and endogeneity in the form of an omitted explanatory variable (that follows a spatial autoregressive process) that exhibits non-zero covariance with the variables in the model. These plausible circumstances observed in applied spatial growth regressions make the SDM model the econometric choice over competing alternatives. ${ }^{15}$ 
In the context of growth models, the underlying theoretical justification for the inclusion of spatial spillovers stemming from both dependent and independent variables in the form of a SDM specification is provided by ERTUR and KOCH (2007). They propose an augmented Solow model that modifies the aggregate level of technology to account for spatial externalities and technological interdependencies across economies. Solving the model for the steady-state and conditional convergence equation, the modified model produces a functional specification that includes spatial lags of both dependent and explanatory variables in which the value of the parameter $\rho$ can be interpreted as a measure of the degree of interregional spillovers stemming from technological interdependence. In other words, the SDM model is also the empirical specification to capture externalities considered in growth theory. ${ }^{16}$ As Equation (1) is considered in the literature a generalised ad hoc specification of SoLOW (1956) and MANKIW (1992), Equation (4) can be considered a generalised case of ERTUR and KoCH (2007). In addition, generalising the model allows the researcher to analyse the spillover mechanisms working through SMEs and entrepreneurship as discussed in section 2. For instance, PiJnEnburg and KhOlODILIN (2012) use this strategy and estimate a SDM model to analyse the effect of entrepreneurship in a specific region and in its neighbourhood on economic output.

Importantly, the spatial econometrics literature has shown that OLS estimation is inappropriate for models incorporating spatial effects. In the SEM specification, parameters' estimation will be unbiased, but inefficient due to the non-spherical structure of the disturbance variance matrix. The OLS estimator will be biased and inconsistent for the parameters of the SAR model due to the simultaneity in the nature of the spatial autocorrelation process caused by the introduction of the spatial lag. ${ }^{17}$ Thus, inferences are based on the maximum likelihood estimator proposed in ANSELIN (1988) and extended for panel data by ELHORST (2010a). Panel data models have advantages over cross-section ones 
as they have more degrees of freedom, can control for individual and time fixed effects, and contain less collinearity among the variables in the model. In this paper, the spatial panel estimations use the developments made by ElHORST (2010a). He shows that maximum likelihood estimations of spatial panel models with fixed effects can be carried out after demeaning the variables in the model in order to control for the space-specific and time fixed effects. ${ }^{18}$

\section{Data, Spatial Matrices and Exploratory Spatial Data Analysis}

\section{Data}

The analysis makes use of a dataset combining micro-regional data with the aggregate results of individual establishment data to account for the SMEs measures at micro-regional level. The micro-regions are administrative regions consisting of municipalities that share a common geographic area and characteristics. This regional dataset provides a large number of observations and reduces the distortions observed at municipality level. Accordingly, the analysis performed in the paper allows to draw inferences only about the process of economic growth at the micro-regional level. Changes in the geographical unit of analysis might suggest a different relationship among the variables of the model, a phenomenon known as the modifiable areal unit problem (MAUP), which is discussed in detail in OPENSHAW (1984). ${ }^{19}$

Real GDP at factor prices, defined as GDP deflated by the national GDP deflator, for each micro-region $(G D P)$ was collected from IBGE (Brazilian Institute of Geography and Statistics) and IPEA (Institute of Applied Economic Research). The data points for this series are: 1980, 1985, 1996, 2000 and 2004. The data are organised in intervals as closely as possible to 5-years to mitigate business cycle influences (e.g. CASELLI et al., 1996; BADINGER 
et al., 2004; DING AND KNIGHT 2009), according to the data availability. This series constitutes the main constraint in terms of data availability for the construction of the panel dataset (see Appendix A for more details). From these data points, the average annual growth rates for each time span were calculated for the GDP per capita variable.

For the control variables included in vector $X$, the data for population growth $(n)$ were collected from IBGE and the data on average years of schooling of the population aged over 25 years (School) were taken from IPEA ${ }^{20}$. In addition, the RAIS (Brazilian Annual Report of Social Information of the Ministry of Labour) dataset was used to construct the SME measures. RAIS is a comprehensive administrative census dataset that starts in 1985 and covers the formal sector of the economy with demographic information for workers and establishments $^{21}$. Firstly, we constructed the relative size of the small and medium enterprise sector $(S M E R)$, measured by the share of the SME sector employment in the total formal labour force in manufacturing, using the cut-off of 250 employees, as in BECK et al. (2005) and AyYAgARI et al. (2007). Secondly, following MuEndLER (2007) and Cravo et al. (2012), numbers of years of schooling were attributed to each level of educational attainment provided by RAIS to generate a continuous series and construct the new variable for the average years of schooling in SMEs in manufacturing $(S M E H)$ as follows ${ }^{22}$ :

$$
S M E H=\frac{\sum_{i=0}^{N}\left(E^{i} \times S^{i}\right)}{E}
$$

where $E^{i}$ is the number of SME employees in each range of education, $S^{i}$ is the number of years of schooling for that particular range and $E$ is the total number of SME employees. ${ }^{23}$

The final data panel is a balanced one for 1985 to 2004 with 508 (out of 558) Brazilian micro-regions, organised in intervals as close as possible to a 5-year span to mitigate business 
cycles influences. ${ }^{24} \mathrm{~A}$ drawback of the dataset is the paucity of information about physical capital at this regional level, and it is plausible to assume that a substantial part of the initial stock of physical capital is captured by the initial GDP per capita level.

\section{Spatial Matrices and Exploratory Spatial Data Analysis}

A simple way of modelling the spatial structure is based on the queen contiguity spatial matrix, where regions that share a common border are assigned the value of 1 and regions that do not are assigned the value of 0 . The resulting matrix is row-standardized to form the spatial weight $W$, where the elements of a row sum up to one. Four spatial weights based on the queen contiguity structure from the first to the fourth spatial lag order were constructed. ${ }^{25}$ Alternatively, row-standardised spatial weights based on the k-nearest neighbours are calculated from the distance between regions centroids as in LE GALLO and ERTUR (2003). Matrices based on 20, 40 and 60 nearest neighbours were constructed. Nevertheless, the matrices mentioned above are simpler binary representations of the spatial structure and do not represent the real dimension of distance. To overcome this limitation, a weight matrix expressed as the inverse of the square road distance between each pair of micro-regions is used to account for the intuition that closer regions are more related than further regions. ${ }^{26}$

Table 1 reports the results of Moran's I statistic for all variables included in Equation (1). Regardless of the spatial structure imposed, all variables present a positive association between the original variable and its spatially lagged version. Therefore, each region should not be viewed as an independent observation, as implicitly assumed in many studies of regional growth (REY and MONTOURI, 1999). This spatial autocorrelation can also be visualized in Figure 1, which shows the Moran scatterplot for the GDP per capita in 1980 using the inverse squared distance weight matrix. ${ }^{27}$ 
[Insert Table 1 here]

[Insert Figure 1 here]

Additionally, the local indicator of spatial autocorrelation (LISA) assesses the significance of local spatial clustering around an individual location and identifies pockets of spatial nonstationarity (ANSELIN, 1995). ${ }^{28}$ Figure 2 presents the LISA significance map for the GDP per capita in 1980 using the inverse square distance weight and suggests a criterion to divide our initial sample and control for space heterogeneity. It indicates the presence of two significant regional regimes with a cluster of high-high values in the Southern part of Brazil and another of low-low values dominating the spatial pattern in the Northern part of the territory. ${ }^{29}$ The presence of two spatial regimes is in line with SILVEIRA-NETO and AzZONI (2006) who suggest the existence of one geographical income cluster in the Southern part of the country, encompassing South, Southeast and Centre-West states, and another one grouping states in the Northern part of the territory (North and Northeast states). There seems to be a clear Northern-Southern polarization in Brazil that is also in line with LAURINI et al. (2005). Therefore, the exploratory analysis confirms the presence of spatial autocorrelation and spatial heterogeneity that need to be considered when estimating growth models.

[Insert Figure 2 here]

5. Empirical Results 
The existing economic growth literature provides evidence of convergence for Brazilian regions. It suggests that convergence is conditioned on structural factors such as population growth, physical capital and human capital, using either standard econometrics (e.g. LAU et al., 1993; Ferreira, 2000; AZZONI, 2001; NAKABASHI and SAlvato, 2007; Cravo, 2010) or spatial econometrics (e.g. SiLveIRA-Neto and AZZONI, 2006; RESENDE, 2011). However, there are no studies considering growth with spatial spillovers in a panel data setting for Brazil. Also, the international literature that incorporates the SME sector into the growth framework and considers the spatial dependence in the analysis is scant and limited to developed countries, and so the evidence considering this dimension in the context of a developing country might add to the understanding of how SMEs influence economic growth.

Regression results obtained from estimating the non-spatial Equation (1) and its spatial variants using the row-standardised inverse squared distance spatial weight are presented in Table 2. Firstly, column 1 reports the non-spatial OLS-within estimation results (controlling for space and time fixed effects) and the LM diagnostic tests for spatial dependence that refer to the spatial model as the alternative to the non-spatial OLS model ${ }^{30}$.

The results in column 1 indicate that the model suffers from spatial dependence, since the LM tests are statistically significant and reject the null hypothesis of no spatial dependence. Interestingly, all panel data estimates (columns 2 to 4) present similar qualitative results for the original variables (non-spatially lagged variables) that they have in common. Also, the scalar spatial error coefficient, $\lambda$, or the spatial autocorrelation parameters, $\rho$, are positive and significant, confirming the importance of spatial effects in all estimates. Nevertheless, the SDM model is the only specification that sheds light on how spatial effects work through dependent and independent variables as described in Section 2 and is argued to be the best econometric choice. Besides, the fit of the SDM specification expressed by log- 
likelihood (LIK) is the best among the three spatial panel alternatives and provide additional support to these arguments.

\section{[Insert Table 2 here]}

In the results for the SDM specification (column 4), the coefficients of the original independent variables represent the direct effect on growth, and the coefficients of the spatially lagged independent variables capture the spillover effects of those variables on growth. For instance, the spatial autoregressive parameter, $\rho$, can be interpreted as the magnitude of interregional spillovers stemming from technological spatial interdependence (e.g. ERTUR AND KOCH, 2007). The magnitude of this coefficient suggests that per capita GDP growth changes by 0.774 percentage points in association with an additional one percentage point increase in the per capita GDP growth of neighbouring micro-regions. ${ }^{31}$ In addition, the positive and significant coefficient of the spatial lag of the initial GDP per capita level supports the idea that higher levels of GDP in neighbouring regions impact positively on economic growth in a given region. ${ }^{32}$

The coefficients of population growth and its spatially lagged variable are negative and insignificant. The fact that the former is not negatively significant is contrary to the Solow growth model prediction, but in line with the literature about Brazil. NAKABASHI and SALVATO (2007) argue that this result might be related to the endogeneity between economic and population growth, the population from poorer areas of the country (endogenously) migrates to look for better living conditions in areas that present faster growth and presumably more employment opportunities. The coefficient of human capital is positive and significant, indicating that localised investments in education at micro-regional level are important to promote economic growth. Conversely, the interaction of human capital across 
space is negatively related to growth. These negative human capital spillovers at regional level were also found in LeSAGE and FISHER (2008) and OLEJNIK (2008) for the European NUTS 2. As argued in OLEJNIK (2008), the level of human capital in neighbouring locations has a negative influence on the level of per-capita income in a given region. This is because an increase in the level of human resources in one region is caused mainly by migration of the educated population from neighbouring regions. Qualified workers seem to be attracted to one location, and the concentration of more qualified people in this region does not translate into human capital spillovers to the neighbouring regions that supplied the human capital ${ }^{33}$.

With regards to the SME sector, the estimates show that SMER is negatively related to economic growth. This result is in line with the existing standard a-spatial panel data evidence for Brazil (e.g. CRAvo, 2010; CRAvo et al., 2012) and with the idea that entrepreneurial activity in Latin America is driven by necessity entrepreneurship (Acs and Amorós, 2008). Local institutional factors may hence prevent SMEs from reaching their full potential and therefore from contributing to growth. The results provided by the spatial panel regressions confirm this empirical regularity for the Brazilian case but also allow to check the effect of possible spatial interactions stemming from SMER on regional growth. The interaction of SMER across space is positive and significant, suggesting that the size of the SME sector in neighbouring regions contributes to economic growth.

The presence of more SMEs in neighbouring regions seems to induce a more productive entrepreneurship and new economic possibilities that affect economic performance positively. AUDRETSCH and KEILBACH (2007) argue that entrepreneurial activities have a more positive influence on neighbouring regions than on distanced regions due to cultural aspects, for instance. Using data for Germany, they provide evidence that an increase in entrepreneurial activity in adjacent regions increases entrepreneurship in a given region. This is in line with BRUCE et al. (2009) who provide evidence that SMEs activities affect economic 
growth in neighbouring states in the U.S. ${ }^{34}$ Nevertheless, the above-mentioned papers do not elaborate on the channels through which entrepreneurship benefits neighbouring regions. As discussed in Section 2, the positive effect stemming from the size of the SME sector in neighbouring regions is in line with the argument that a larger number of firms in the neighbouring regions might reinforce competition and thus affect positively economic growth in the given region. PIJNENBURG and KHOLODILIN (2012), based on regional data for NUTS-3 in Germany, found that entrepreneurship in neighbouring regions is correlated with better economic performance in a given region. They suggest that this result is evidence that entrepreneurship in neighbouring regions reinforces competition in a given region. Also, demonstration externalities might be another route to explain the mechanisms through which SMEs reinforce competition and to better understand the empirical findings. According to ACS and VIRGILL (2009) there are important spillover effects from having examples of business formation and from entrepreneurs observing successful entrepreneurial initiatives. Additionally, potential and existing entrepreneurs learn from failing and failed businesses. They learn what not to do or what to do differently, and this is likely to reinforce competition. Thus, ACS and VIRGILL (2009) argue that the aim of policy makers should be to ensure a playing field where all potential entrepreneurs have an opportunity to generate and benefit from the demonstration externalities. ${ }^{35}$

Regarding the human capital of SMEs, the variable $S M E H$ has a coefficient with the opposite sign from that associated with the spatial lags of this variable. Higher levels of human capital in SMEs are positively related with growth in the same region, indicating that this aspect of SMEs is more important than the size of this sector for promoting economic growth. This result confirms the theoretical propositions discussed in Section 2 (e.g. QIAN and ACS, 2013, and QIAN et al, 2012). It thus supports the argument that human capital is conducive to economic growth through the mechanism of enhancing the absorptive capacity 
of SMEs. Moreover, following Poschke (2013), higher SME human capital may imply that the motivation for entrepreneurship was opportunity-based rather than necessity-based, and hence there is a positive impact on economic growth. From a policy point of view these issues suggest that if education measures raise human capital and this raises the ratio of opportunity to necessity entrepreneurship, and/or productivity in the SME sector, e.g. through innovation or imitation, a positive effect on economic growth can be expected.

However, the negative and not significant sign of the spatial lag of $S M E H$ does not support the idea that regions benefit from a higher level of human capital in SMEs in neighbouring areas. The interpretation of this result follows the same pattern as that of a negative externality of the overall level of human capital (e.g LESAGE and FISHER, 2008; and OLEJNIK, 2008) discussed in Section 2: The level of SMEs human capital in neighbouring regions may be negatively associated with the level of per capita income in a given region, because an increase in the level of human capital in the neighbouring region is caused mainly by attracting skilled labour away from adjacent regions, i.e. through the mechanism of interregional migration of human capital. This reduces SME human capital in the given region, which has a negative effect on growth. Higher levels of human capital do not generate any positive spillovers for neighbouring regions. ${ }^{36}$

Summarising, the presence of SMEs per se does not generate economic growth directly but through spatial interactions. Conversely, the level of human capital applied in the SME sector seems to be more relevant for regional economic growth in Brazil, even though there are no human capital spillovers in the SME sector. ${ }^{37}$ 
The economic growth literature on Brazil (e.g. LAURINI et al., 2005; SILVEIRA-NETO and AZZONI, 2006) and Figure 2 suggest the existence of two different spatial regimes, one in the Northern Brazil (Northeast and North regions) and another in the Southern part of the territory (South, Southeast and Centre-west regions). This spatial heterogeneity might cover some distinctive patterns specific for those regimes that are not captured by the estimates for the country. Therefore, two alternative samples for the regional analysis are considered. The first regional sample comprises 207 contiguous micro-regions in the poorer Northern part of Brazil and the second sample comprises 301 contiguous micro-regions in the richer Southern part of the country ${ }^{38}$. This procedure is in line with LE GALLO and DALL'ERBA (2006) and RAMAJO et al. (2008), who estimated spatial growth regressions for two spatial regimes in the European

\section{Union NUTS II.}

Table 3 reports the results for the two spatial regimes based on the row-standardised inverse squared distance spatial weight, and the focus is on the estimations of the SDM model. Column 3 reports the SDM results for the Northern regions, that are in line with the results for the country as a whole. The autoregressive parameter suggests the existence of interregional spillovers, and the spatial lag of initial GDP per capita indicates that better-off neighbours impact positively on the economic performance of a given region. Regarding the SME sector, SMER is negatively related with per capita GDP growth. Conversely, the coefficient of $S M E H$ is positive, indicating that this aspect of SMEs is more important than the size of this sector for economic performance. The proxies related to the SME sector have coefficients with the opposite sign from those associated with the spatial lags of these variables. The insignificant negative sign of the spatial lag of $S M E H$ indicates that a given region does not benefit from a higher level of human capital in SMEs in the neighbouring regions, while the positive and significant sign of the spatial lag of SMER indicates that a given region benefits from entrepreneurial activities in neighbouring regions. 
The SDM model estimation for the Southern regions is presented in column 6. In light of Ertur and Koch (2007), results for the coefficient of the autoregressive parameter show stronger spatial interregional spillovers and suggest stronger technological interdependence generated by the growth rates in neighboruring regions when compared with the results for the country as a whole and the Northern regions. ${ }^{39}$ Additionally, the spatial lag of initial GDP per capita suggests that a given region achieves a better economic performance when its neighbours are richer. Human capital seems to be an important growth determinant for this set of regions, but as in the case of the country as a whole, the coefficient of the spatial lag of human capital presents a negative sign. Regarding the results for the SME sector, the coefficient of SMER is negatively related with economic growth and we cannot rule out a positive effect of SMEH on GDP per capita growth. Thus, these results confirm that the size of the SME sector is not important to economic performance. Also, although there is no robust evidence of a positive effect of human capital in SMEs on growth, the idea that SMEH might impact positively economic performance in the Southern regions cannot be ruled out. ${ }^{40}$

[Insert Table 3 here]

Overall, the regional results are in line with the analysis for the country as a whole and show that externalities detected for the country as a whole were not a result of the omission of spatial regimes and is a phenomenon that occurs within each regime as well. Moreover, SMER is negatively correlated with economic growth in all samples, and the SME sector seems to affect growth via the micro-regional human capital embodied in SMEs, evidenced by the positive sign of the coefficient of $S M E H$. In addition, results indicate that a given 
region does not benefit from higher levels of human capital embodied in SMEs in the neighbouring regions, regardless of the group of regions analysed. ${ }^{41}$

Nevertheless, some differences emerged in the regional analysis in terms of the level of significance and magnitudes of the coefficients. For instance, in the Southern region, there is no significant indication that a given region benefits from a bigger SME sector in neighbouring regions. Another difference is that the Southern regions seem to be more connected economically with neighbours as evidenced by the greater magnitude of the spatial autoregressive parameter and the coefficient of the spatial lag of the initial GDP, results that might be related with the fact that the distances between Southern regions are shorter. Moreover this stronger economic connectivity might be influenced by some externalities associated with the new economic geography models. For instance, KRUGMAN (1999) argues that Brazil's south is a more attractive place to produce due to better transport infrastructure and higher market potential. ${ }^{42}$ Thus, Southern Brazil attracts firms and investments that want to exploit economies of scale and access to consumers. In relation to the SME sector, as argued in AUDRETSCH and KEILBACH (2007), entrepreneurship might be linked to cultural phenomena that are clustered in space. Hence, differences in the regional empirical results with regards to SMEs are in line with the idea that small business activities are influenced by local cultural and institutional differences.

\section{Conclusion}

This paper has analysed the importance of the SME sector for the process of economic growth in Brazilian micro-regions using spatial panel econometrics. The results show that growth rates in a given micro-region are affected positively by the level of the GDP per capita and its growth in neighbouring regions, a clear indication of the spatial dependence of the economic 
activity. Noticeably, human capital is an important growth determinant, but there is no indication of positive human capital spillovers and this finding reinforces the need of localised investments in human capital. There is indeed some evidence of negative human capital externalities, as the level of human capital in neighbouring locations has a negative influence on the economic performance of a given region. This suggests possible regional competition for human capital, which is in line with the idea that qualified workers seem to migrate to one region that offers better jobs and the concentration of more qualified people in this region does not translate into human capital spillovers to the neighbouring regions that supplied the human capital.

Furthermore, the presence of SMEs per se does not generate economic growth directly but through spatial interactions. Small businesses in a given region seem to benefit from a larger presence of SMEs in its surrounding area. This finding is in line with the scant evidence on entrepreneurship spillovers and is related to the idea that more SMEs in neighbouring regions reinforce competition, suggesting a line of action for public policy to promote entrepreneurship and affect growth. A policy that promotes entrepreneurship and provides a level playing field for market competition generates regional externalities and reinforces competition that might affect neighbouring regions. The level of human capital applied in the SME sector seems to be important for local regional economic growth in Brazil. One mechanism through which this takes effect is likely to be an enhancement of the absorptive capacity of SMEs. Furthermore, higher levels of SME human capital may imply that the motivation for entrepreneurship was opportunity-based rather than necessity-based, and hence there is a positive impact on economic growth. Policy measures that stimulate the formation of human capital locally might thus raise economic growth. On the contrary, the results suggest that there are no human capital spillovers in the SME sector. 
Measures of global and local spatial autocorrelation suggest the existence of spatial dependencies and indicate the presence of two spatial regimes in Brazil. In general, the analysis of the two different regimes is in line with the results for the country as a whole. For instance, human capital embodied in SMEs also seems to be more important than the size of this sector for regional economic growth but does not generate positive spatial spillovers either. However, there are some differences between the two spatial regimes, which are consistent with the argument that the technological spillover is stronger in Brazil's Southern regions and that entrepreneurship and SMEs are influenced by local characteristics.

In sum, the empirical evidence does not support the public policy view that the size of the SME sector should be locally increased per se to improve economic performance. Instead, policy makers should take into account the spatial interactions of directly supporting SMEs in a given region to promote growth by reinforcing competition. Thus, it would be desirable for SME policy to be coordinated with a broader regional focus in order to explore entrepreneurship externalities. If the policy emphasis is on localised direct support to SMEs, educational policies should be a focus of public policy by enabling more human capital formation for the economy and for a more productive SME sector that can contribute to the process of economic growth. This paper has provided the first tentative analysis of the economic growth process in Brazil, and the importance of aspects of the SME sector in this process, considering spatial dependence in a panel data set up. Although the paper provides interesting results, the exact mechanisms through which spatial spillovers in the SME sector affect growth are not analysed in depth, and this issue is an important avenue for future research. 


\section{Acknowledges}

I would like to thank two anonymous referees for their valuable comments and suggestions which helped us to improve the paper.

\section{Notes}

1. For the same period, the International Finance Corporation (IFC) of the World Bank Groupd investment portfolio identified as benefiting SMEs amounted to US\$25 billion between 2006 and 2012.

2. The study of BECK et al. (2005) is based on a broad cross-section of 45 countries and includes countries with different levels of development.

3. This literature uses two types of proxies for entrepreneurship activities. The start-up rates used in AUDRETSCH and KEILBACH (2004) is a dynamic measure of entrepreneurship, and the stock of SMEs' employment used in BECK et al. (2005) is a static measure. These measures represent different dimensions of entrepreneurship but are related concepts. Higher small businesses start-up rates will lead to a higher share of workers in the SME sector, while a higher mortality rate will adjust the size of this sector in opposite direction (CRAVO et al., 2012).

4. See section 2 for a detailed conceptual discussion of the mechanisms through which spatial spillovers may affect growth.

5. The paper also considers spatial spillovers stemming from factors such as GDP per capita income, human capital and population growth, which are extensively documented in theoretical and empirical papers in the economic growth literature (e.g. ReY and Montouri, 1999; ERTUR and Koch, 2007; MOHL and HAGEN, 2010).

6. The country's government recognizes the importance of this sector, with the budget of the Brazilian Small Business Support Service (SEBRAE) amounting to approximately US\$ 1.6 billion in 2012, for instance. SEBRAE is not a government agency, but approximately $75 \%$ of its budget comes from taxes collected by the Brazilian federal government. 
7. Clusters tend to occur in a spatially delimited area, as argued by ALTENBURG and MEYER-STAMER (1999), but might span across the borders of several regions (e.g. CARROLL et al., 2008).

8. This cultural characteristic can increase entrepreneurship in a region and thus competition, which might impact the efficiency of the regional economy and generate growth.

9. The authors present results, based on data for the US, indicating that the direct effect of human capital (via absorptive capacity) on entrepreneurship is much stronger than its indirect effect via new knowledge. This implies that human capital contributes to entrepreneurship primarily by building entrepreneurial absorptive capacity.

10. Institutional constraints impede SMEs in reaching their full potential and do not stimulate productive entrepreneurship that could contribute to reinforce competition and increase economic efficiency that leads to economic growth.

11. PosCHKE (2013), based on a cross-section of countries, argues that the concept of necessity entrepreneurship is related to entrepreneurs who have lower education, run smaller firms and expect their firms to grow less. Still, POSCHKE (2013) presents results that suggest that necessity entrepreneurs are likely to stay in the market and concludes that policies intended to promote small firms because of their expected contribution to growth have to be implemented with particular care in the context of necessity entrepreneurship.

12. In a ranking of 32 countries, Brazil is at the bottom and presents the worst ratio of opportunity to necessity entrepreneurship (ACS et al. 2008).

13. The same level of entrepreneurship might lead to a different impact on growth if the U-shaped relationship between entrepreneurship and development is true.

14. Analogous to time series models where lagged values of the dependent variable are often included to account for missing explanatory variables, a similar motivation can be used for spatial lags of the dependent variable in cases where spatial dependence is likely to occur (ABREU et al. 2005) 
15. For instance, LESAGE and FisHER (2008) point out that data on physical capital are not available and omitted in most regional growth regressions.

16. See also FISCHER (2011) who suggests a similar model that leads to a spatial Durbin model (SDM) as the econometric specification.

17. In the SAR model, the spatial lag is an average of neighbouring values and leads to a connectivity relation where the covariance of the error term between two regions is not zero.

18. The log-likelihood functions for spatial panel data and the demeaning process to remove time and space (individual) fixed effects are detailed in ELHORST (2010a).

19. RESENDE (2011) discusses MAUP for regional growth regressions in Brazil and shows that spillover effects change with the geographical scale of analysis.

20. The data for the variable School are available only in a ten-year time span interval from 1980 to 2000 (based on census data), and data points in between these years were constructed by interpolation. This variable was lagged five years because the year 2000 was the most recent time period available. The population growth variable, $\ln (n+d+g)$, is adjusted for depreciation $(d)$ and technological growth $(g)$, under the usual assumption that $d+g$ equals 0.05 .

21. Every year establishments are obliged to report all required information to the Ministry of Labour. In 2004, RAIS covered 31.5 million workers (97\% of formal employment according to the Ministry of Labour).

22. See Appendix A (Table A.1) for further details.

23. According to the Ministry of Labour, RAIS data present inaccurate information forsmall municipalities (see also Saboia, 2000). This is an additional reason for the use of micro-regions, as this more aggregated territorial unit reduces the bias from inaccurate data for small municipalities. 
24. The sample loses 50 micro-regions located in poor and isolated areas that did not present data at all data points, most of them located in the Amazon region. In 2004, this subset of micro-regions encompassed only $2.3 \%$ of the Brazilian population and so it is reasonable to assume that their omission does not generate a serious bias.

25. A queen spatial weight matrix defines neighbours as locations that share a border or vertex. The first spatial lag considers only the immediate neighbours; the second spatial lag order considers neighbours of neighbours, and so on for further spatial lags.

26. We would like to thank Prof. Eduardo Haddad from USP for providing the road distances for each pair of Brazilian micro-regions. The inverse squared distance spatial weight is also row-standardized.

27. The Moran's I statistic is given by the following expression: $I_{G}=\frac{\sum_{i} \sum_{j} w_{i j} z_{i j} z_{i j}}{\sum_{i} z_{i}^{2}}=\frac{Z^{\prime} W Z}{Z^{\prime} Z}$, where $\mathrm{Z}$ is the vector of a given variable in deviation from its mean and $\mathrm{W}$ is the spatial weight matrix.

28. This index is expressed as follows: $I_{i}=\frac{z_{i} \sum_{j} w_{i j} z_{j}}{\sum_{i} z_{i}^{2}}$, where variables are defined as in the Moran's $I$.

29. Significant high-high values are only found in the Southern regions (Southeast, South and Centre-west), while significant low-low values are found in the Northern regions (Northeast and North), with the exception of three regions on the border between the two clusters, which are located in the north of the Minas Gerais state. Including these regions in the richer Southern regions is justified because Minas Gerais as a whole is a rich state. This follows Ramajo et al. (2008) who grouped Italian poor regions together with the core of Italian regions because Italy as a whole is a rich country. Alternative LISA maps based on simpler binary spatial weights are reported in Appendix B and confirm the pattern observed in Figure 2. The Southern region has 301 micro-regions and Northern 207 micro-regions.

30. See ANSELIN et al. (1996) for more details about the LM tests. As an alternative, the inverse squared distance standardized by its largest eigenvalue is used to comply with the stationary requirement without losing quantitative information on distances (see ANSELIN (1988), p. 23-24 and ELHORST (2010a), p. 3-4). Estimation results based on this matrix are presented in the Appendix (Table A.4) and provide similar qualitative results. 
31. It is important to note that we do not imply causality, since the spatial panel estimators used in the regressions are not able to treat endogeneity related to the independent variables. Nevertheless, the estimator used in this paper accounts for the endogeneity coming from the spatial lag of the dependent variable (see ELHORST, 2010a). For a discussion of the causality identification problems in spatial models, see GIBBONS and OVERMAN (2010).

32. This means that regions with the same parameters can have different growth rates if their neighbours have different levels of GDP per capita, possibly due to different physical capital endowments. Thus, this result can also be interpreted as the spatial externalities stemming from physical capital. As noted in LÓPEZ-BAZO et al. (2004), an alternative interpretation to this lies in the fact that some of the spillovers could have been caused by pecuniary externalities present in models of new economic geography (e.g. KRUGMAN, 1991).

33. This reasoning is in line with the argument linked to New Economic Geography models, that more skilled labour is an important mobile factor that constitutes a centripetal force towards geographical concentration (e.g. KRUGMAN, 1999).

34. In line with the results provided in this paper, Table 3 of BRUCE et al. (2009) suggest that for the US states a larger number of small business establishments is not related to higher rates of economic growth (the coefficient is negative, as in this paper, however is not significant). On the other hand, they also found that the number of small firm establishments in neighbouring states have positive effects on growth.

35. Importantly, the externalities captured in the general context of SMEs does not identify to which extent the more specific spillovers generated by joint actions in clusters of SMEs described in SCHMITZ (1995) influenced the results. Thus, disentangling the general SME spillovers from the more specific spillovers generated by clusters of SMEs remains a challenge for future research.

36. The results of the SDM model might be affected by multicollinearity due to the use of spatial lags of all variables in the model, especially the two proxies of human capital used. Table A.2 in the appendix provide the correlations among the variables considered in the regressions and show high cross-correlations among $\ln S C H O O L, \ln S M E H$, $\ln S C H O O L^{*} \mathrm{~W}, \ln S M E H^{*} \mathrm{~W}$. As a robustness test, these variables were dropped and results reported in Table A.3 (columns 1 to 4 ) are in line with the baseline regressions in Table 2. The regression coefficient signs are always 
consistent with the baseline results and the level of significance is similar most of the times. The panel data used in this paper comprises a large number of regions, which helps to reduce collinearity problems.

37. The results reported in the main text are based on the manufacturing sector, as the data for the SME sector used in this paper are for the formal sector of the economy and manufacturing is characterised by higher rates of formality. This limitation was also a shortcoming identified by BECK et al. (2005), who argue that it would be useful to have information on SME employment beyond manufacturing. In order to consider this limitation, alternative results for an extended SME sector considering manufacturing, commerce and services (SMER) are included in Table A.3 (Column 4) in the appendix, as in CRAVO et al.(2012). The estimations for a broader SME sector provide similar qualitative results when compared to the baseline regressions in Table 2.

38. Considering two groups of contiguous regions separately implicitly assumes that there are barriers preventing spatial spillovers from one cluster to another in order to better observe structural differences within each cluster. For instance, ACEMOGLU et al. (2001) provide evidence that GDP per capita and the quality of institutions are positively related, and NARITOMI et al. (2009) document that income per capita is positively related with institutional development in Brazil. Thus, spatial regimes might be related with different institutional regimes where the cluster of poorer regions has a worse institutional quality.

39. The channels through which technology spills over across regions in Brazil is an important route for future research. Nevertheless, the smaller distances between micro-regions in the Southern region might facilitate interregional spillovers generated from technological interdependence. The average area of the micro-regions of the Southern group is $11714 \mathrm{Km}^{2}$ and for Northern group is $17956 \mathrm{Km}^{2}$.

40. Alternative results using the eigenvalue standardised inverse squared distance weight matrix are presented in Appendix D (Tables A.4) and provide the same qualitative results, the coefficients that are significant always show the same sign. Also, the robustness results show that $S M E H$ has the same positive sign for the Southern regions but in this case suggests that this association is significant.

41. The relationship between the SME sector variable and economic growth discussed in Section 5 is based on data from 1980 to 2004 as explained in the Appendix A. However, a robustness test removing cross-sections of the data to 
test this relationship for other time periods provided results that are either in line with the main results of the paper or do not provide any evidence against these results (see Table A.5 in the appendix). The main results of the paper are preferred as they use all observations, which is likely to increase variability among the variables and the efficiency of the estimation.

42. The existence of a better common infrastructure could also be important to facilitate demonstration effects, as it will be less costly to travel across neighbouring regions. This is an interesting topic that could be explored in future research to study how infrastructure affects entrepreneurial demonstration effects and spillovers. 


\section{Appendix A: Data}

\section{A.1. Micro-regional real GDP data}

The real GDP at factor prices was constructed from the information available for Brazilian municipalities and aggregated into micro-regions. The available data for the period between 1980 and 1996 are the data points: 1980, 1985 and 1996. The real GDP at factor prices for the above-mentioned period was constructed by IPEA based on IBGE's GDP measurement for Brazilian States. Alternatively, between 1999 and 2004, IBGE calculates the GDP for Brazilian municipalities (from 2004 onwards it uses a new methodology to calculate the GDP that is not comparable with previous GDP data). Originally, IBGE reports the GDP at market prices but provides results for value added and taxes, which allows the calculation of the GDP at factor prices. The GDP at municipality level is calculated by different government institutes (IPEA and IBGE) but always upon IBGE's GDP measurement for Brazilian states using the same methodology. The major difference is that IPEA and IBGE use different proxies to allocate the state's GDP across municipalities, because the same information at municipality level is not available across the years. This data processing may create some measurement errors, but it is the best series for the real GDP at micro-regional level. Problems with regional data are not restricted to Brazil, Many regional studies for the European Union are based on compilations from Cambridge Econometrics that put together data from different statistics offices that are not fully compatible, therefore, being subject to measurement errors (FINGLETON, 2000).

\section{A.2. Range of Education to Generate a Continuous Series for SMEH}

[Insert Table A.1 here] 
Appendix B - LISA Maps

[Insert Figure A.1 here]

\title{
Appendix C. Table of Correlations
}

[Insert Table A.2 here]

\section{Appendix D. Alternative Results for Panel Estimates}

\author{
[Insert Table A.3 here]
}

[Insert Table A.4 here]

[Insert Table A.5 here]

\section{References}

Abreu M, De Groot H, Florax R (2005) Space and Growth: A Survey of Empirical Evidence and Methods. Région et Développement 21: 13-44.

Acemoglu D., Johnson S. and Robinson, JA. (2001) The colonial origins of comparative development: An empirical investigation. American Economic Review 91(5): 1369-1401. 
ACs Z., Amorós, J. (2008) Entrepreneurship and competitiveness dynamics in Latin America. Small Business Economics 31: 305-322

Acs Z., Armington C (2004) Employment growth and entrepreneurial activity in cities, Regional Studies 38(8): 911-927.

Acs Z., Desai S. and Hessels J. (2008) Entrepreneurship, economic development and institutions. Small Business Economics 31(3): 219-234.

ACs Z., VIRGILL N. (2009) Entrepreneurship in developing countries. JENA Economic Research Papers (2009-023). Friedrich Schiller University and the Max Planck Institute of Economics, Jena, Germany.

ACs Z, BRAunerhJelm P, Audretsch D, CARLSSON B (2009) The knowledge spillover theory of entrepreneurship. Small Business Economics 2(1):15-30,

Altenburg T., Meyer-Stamer J (1999) How to Promote Clusters: Policy Experiences from Latin America, World Development 27(9): 1693-1713.

ANSELIN L. (1988) Spatial Econometrics: Methods and Models. Kluwer, Dordrecht.

ANSELIN L. (1995) Local Indicators of Spatial Association-LISA. Geographical Analysis 27: 93-115. 
Anselin L., Bera AK., FloraX R. and YoOn MJ. (1996) Simple diagnostic tests for spatial dependence. Regional Science and Urban Economics 26(1):77-104.

Arbia G., Le Gallo J. and Piras G. (2008) Does Evidence on Regional Economic Convergence Depend on the Estimation Strategy? Outcomes from Analysis of a Set of NUTS2 EU Regions. Spatial Economic Analysis 3(2):209-224.

Audretsch D. and KeILbaCH M. (2004) Entrepreneurship capital and economic performance. Reginal Studies 38(8): 949-959.

Audretsch D. and KeIlBACH M. (2007) The Localisation of Entrepreneurship Capital: Evidence from Germany. Papers in Regional Science 86(3): 351-365.

Audretsch D., DohSE D and Niebuhr A (2010) Cultural diversity and entrepreneurship: a regional analysis for Germany. Annals of Regional Science 45: 55-85.

Ayyagari M., Beck T. And Demirguc-Kunt A. (2007) Small and medium enterprises across the globe. Small Business Economics 29(4): 415-434.

Azzoni C.R. (2001) Economic growth and regional income inequality in Brazil. Annals of Regional Science 35(1): 133-152.

BADINGER H, MÜller WG, TONDL G (2004) Regional convergence in the European Union, 1985-1999: a spatial dynamic panel analysis. Regional Studies 38(3):241-253 
BARRO R. (1991) Economic growth in a cross section of countries. Quarterly Journal of Economics 106(2): 407-43.

BAUMOL W. (1968) Entrepreneurship in Economic Theory. American Economic Review 58(2): 64-71.

BAUMOL W. (1990) Entrepreneurship - Productive, unproductive, and destructive. Journal of Political Economy 98(5): 893-921.

BeCK T., DeMIRGuC-KunT A. and LEvinE R. (2005) SMEs, growth, and poverty: CrossCountry evidence. Journal of Economic Growth 10(3): 199-229.

Bruce D., Deskins J., Hill B AND RoRk J. (2009) (Small) Business activity and state economic growth: does the size matters. Regional Studies 43(2), 229-245.

Carroll M.C., ReID, N., SMith, B.W. (2008), Location quotients versus spatial autocorrelation in identifying potential cluster regions, Annals of Regional Science, vol. 42, no. 2, pp. 449-463.

Caselli F., Esquivel G. and Lefort F. (1996) Reopening the Convergence Debate. Journal of Economic Growth 1(3): 363-389.

CRAvo T (2010) SMEs and Economic Growth in the Brazilian Micro-regions. Papers in Regional Science 89(4): 711-734. 
Cravo T., Gourlay A. and Becker B. (2012) SMEs and Regional Economic Growth in Brazil. Small Business Economics 38(2):217-230

DiAs J. and McDermotT J. (2006) Institutions, education, and development: The role of entrepreneurs. Journal of Development Economics 80(2): 299-328.

DiNG S, KNIGHT J (2009) Can the augmented Solow model explain China's remarkable economic growth? A cross-country panel data analysis. Journal of Comparative Economics $37,432-452$.

ElHorst J.P. (2010a) Spatial Panel Data Models. In Fischer M, Getis A. (eds) Handbook of Applied Spatial Analysis. Springer, Berlin.

ElHORST J.P. (2010b) Applied Spatial Econometrics: Raising the bar. Spatial Economic Analysis. 5(1): 9-28.

ERtur C., Le Gallo J. and BAumont C. (2006) The European regional convergence process, 1980-1995: Do spatial regimes and spatial dependence matter? International Regional Science Review 29(1): 3-34.

ERTUR C. and KocH W. (2007) Growth, technological interdependence and spatial externalities: theory and evidence. Journal of Applied Econometrics 22(6):1033-1062. 
FERREIRA A. (2000) Convergence in Brazil: Recent trends and long-run prospects. Applied Economics 32(4): 479-489.

FInGLETON B. (2000) Spatial econometrics, economic geography, dynamics and equilibrium: a ‘third way'? Environment and Planning A 32: 1481-1498.

FISCHER M (2011) A Spatial Mankiw-Romer-Weil model: theory and evidence. Annals of Regional Science 47(2): 419-436.

FRITSCH M., MUELLER P (2004) Effects of new business formation on regional development over time, Regional Studies 38(8): 961-975.

GibBons S. and OvERMAN H. (2010) Mostly Pointless Spatial Econometrics? SERC Discusson Paper 61, LSE.

GRIfFith R., RedDing S. AND VAn REEnEN J. (2004) Mapping the two faces of R\&D: Productivity growth in a panel of OECD industries. The Review of Economics and Statistics 86: 883-895.

IEG (2013). Evaluation of the World Bank Group's Targeted support for Small and Medium Enterprises. Approach Paper, January.

KRUGMAN P. (1991) Increasing returns and economic geography. Journal of Political Economy 99(3): 483-499. 
KRUGMAn P. (1999) The Role of Geography in Development. International Regional Science Review 22(2): 142-161.

LAU L.J., JAMISON D.T., LIU S. and RIVKIN S. (1993) Education and economic growth: some cross-sectional evidence from Brazil. Journal of Development Economics 41(1): 45-70.

LAURini M., ANDrade E. and VAlls P. (2005) Income convergence clubs for Brazilian municipalities: A non-parametric analysis. Applied Economics 37(18): 2099-2118.

LE GALlo J. and ERTUR C. (2003) Exploratory spatial data analysis of the distribution of regional per capita GDP in Europe, 1980-1995. Papers in Regional Science 82(2): 175-201

Le Gallo J. and Dall'ERBA S. (2006) Evaluating the Temporal and Spatial Heterogeneity of the European Convergence Process, 1980-1999. Journal of Regional Science 46(2): 269-288.

LEVINE R. and RENELT D. (1992) A sensitivity analysis of cross-country growth regressions. The American Economic Review 82(4): 942-963.

LESAGE J.P. and FisCHER M.M. (2008) Spatial Growth Regressions: Model Specification, Estimation and Interpretation. Spatial Economic Analysis 3(3): 275-304.

LESAGE J.P. and PACE R.K. (2009) Introduction to Spatial Econometrics. CRC Press/Taylor \& Francis Group: London. 
Lopez-BAZo E., VAya E. and ArTis M. (2004) Regional Externalities and Growth: Evidence from European Regions. Journal of Regional Science 44(1): 43-73.

MANKIW G., Romer D. and WeIL D. (1992) A contribution to the empirics of economic growth. Quarterly Journal of Economics 107(2) 404-437.

Mohl P. and Hagen T. (2010) Do Structural Funds Promote Regional Growth? New Evidence from Various Panel Data Approaches. Regional Science and Urban Economics, in Press, Accepted Manuscript, doi:10.1016/j.physletb.2003.10.071

MUELLER P. (2007) Exploiting entrepreneurial opportunities: The impact of entrepreneurship on growth. Small Business Economics 28(4): 355-362.

MuENDLER M. (2007) Trade and workforce changeover in Brazil. National Bureau of Economic Research (NBER) Working Papers No. 12980, Cambridge, USA.

NAKABAShi L. and Salvato M. (2007) Human capital quality in the Brazilian States. Revista ANPEC 8: 211-229.

NARITOMi J., SoAReS R. and AssunÇÃo J. (2009) Institutional Development and Colonial Heritage within Brazil. Pontifical Catholic University of Rio de Janeiro (PUC-Rio). Discussion Paper No. 7579.

NELSON R. AND PHELPS E. (1966) Investment in humans, technological diffusion, and economic growth. American Economic Review 56: 65-75. 
OLEJNIK A (2008) Using the spatial autoregressively distributed lag model in assessing the regional convergence of per-capita income in the EU25. Papers in Regional Science 87: 371385

Openshaw (1984) The Modifiable Areal Unit Problem. GeoBooks, Norwich.

Pijnenburg K and KhOlODILIN K (2012). Do regions with entrepreneurial neighbours perform better? A spatial econometric approach for German regions. Regional Studies, in Press, Accepted Manuscript, DOI:10.1080/00343404.2012.697143.

PoschKe M (2013). Entrepreneurs out of necessity: a snapshot, Applied Economics Letters, Taylor and Francis Journals, vol. 20(7), pages 658-663, May.

QIAN H., ACS Z (2013) An absorptive capacity theory of knowledge spillover entrepreneurship. Small Business Economics 40(2):185-197

QIAN H., ACs Z., Stough R (2012) Regional system of entrepreneurship: the nexus of human capital, knowledge and new firm formation. Journal of Economic Geography, in Press, Accepted Manuscript, doi:10.1093/jeg/lbs009.

Ramajo J, Márquez M.A., Hewings G.J.D. and Salinas M.M. (2008) Spatial heterogeneity and interregional spillovers in the European Union: Do cohesion policies encourage convergence across regions? European Economic Review 52(3): 551-567. 
RESENDE G. (2011) Multiple dimensions of regional economic growth: The Brazilian case, 1991-2000. Papers in Regional Science 90(3): 629 - 662.

REY S.J. and MonTOURI B.D. (1999) US regional income convergence: A spatial econometric perspective. Regional Studies 33(2): 143-156.

SABOIA J. (2000) Desconcentração industrial no Brasil nos anos 90: um enfoque regional. Pesquisa e Planejamento Econômico 30(1), 69-116.

SALA-I-MARTIN X. (2002) 15 years of new growth economics: What have we learnt? Universitat Pompeu Fabra Economics and Business Working Paper No. 620.

SCHMITZ H. (1995) Collective efficiency: Growth path for small-scale industry. Journal of Development Studies 31(4), 529-566.

Silveira-Neto R. and AZzoni C.R. (2006) Location and regional income disparity dynamics: The Brazilian Case. Papers in Regional Science 85(4): 599-613.

Solow R. (1956) A contribution to the theory of economic growth. Quarterly Journal of Economic 70(1): 65-94.

Solow R. (2007) The last 50 years in growth theory and the next 10. Oxford Review of Economic Policy 23: 3-14

TEMPLE J. (1999) The new growth evidence. Journal of Economic Literature 37(1): 112-156. 
VAn Stel, A., CARree, M., and ThUrik, R. (2005). The effect of entrepreneurial activity on national economic growth. Small Business Economics, 24(3), 311-321.

Wennekers, S., VAn Stel, A., Thurik, R., and Reynolds, P. (2005). Nascent entrepreneurship and the level of economic development. Small Business Economics, 24(3), 293-309. 


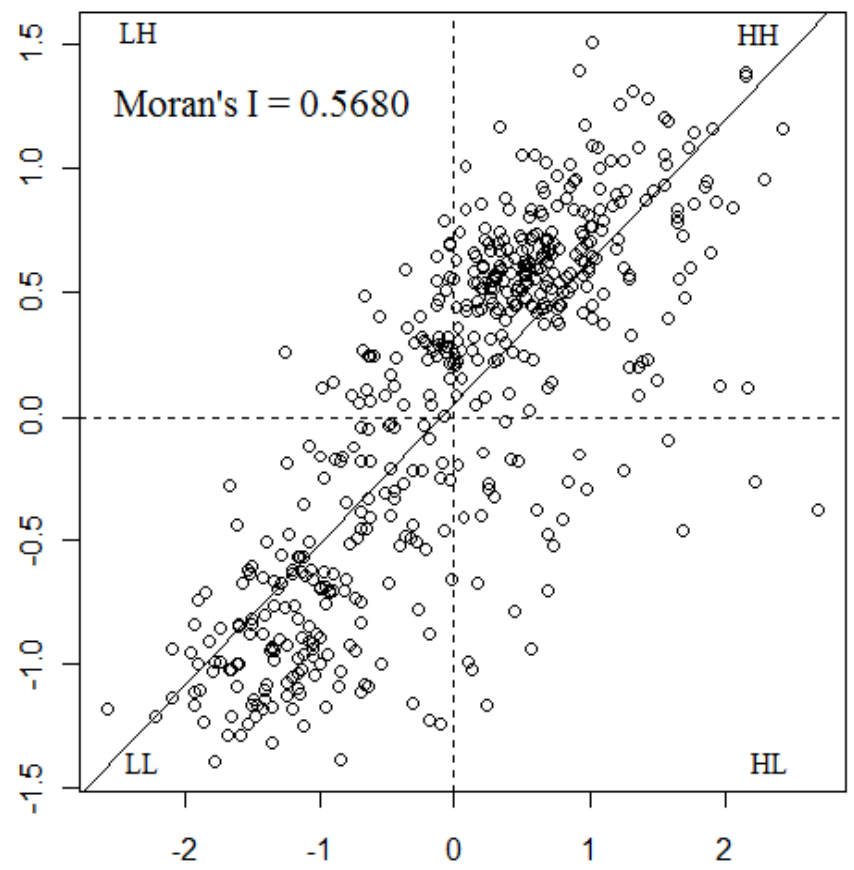

Fig. 1. Moran Scatterplot of $\ln G D P_{t-1}$.

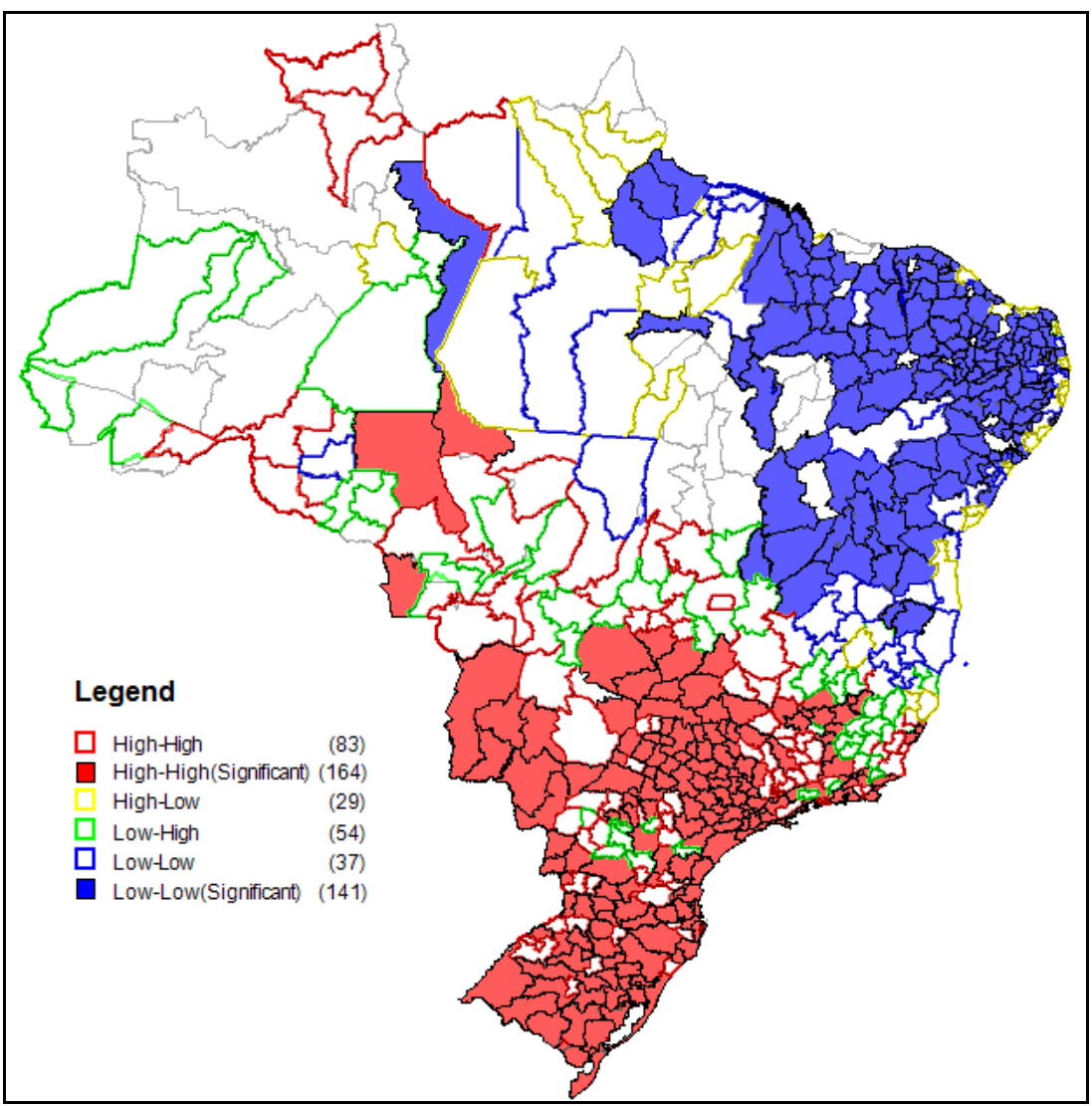

Fig. 2. Local Moran's Significance Map for $\ln G D P_{t-1}$. 


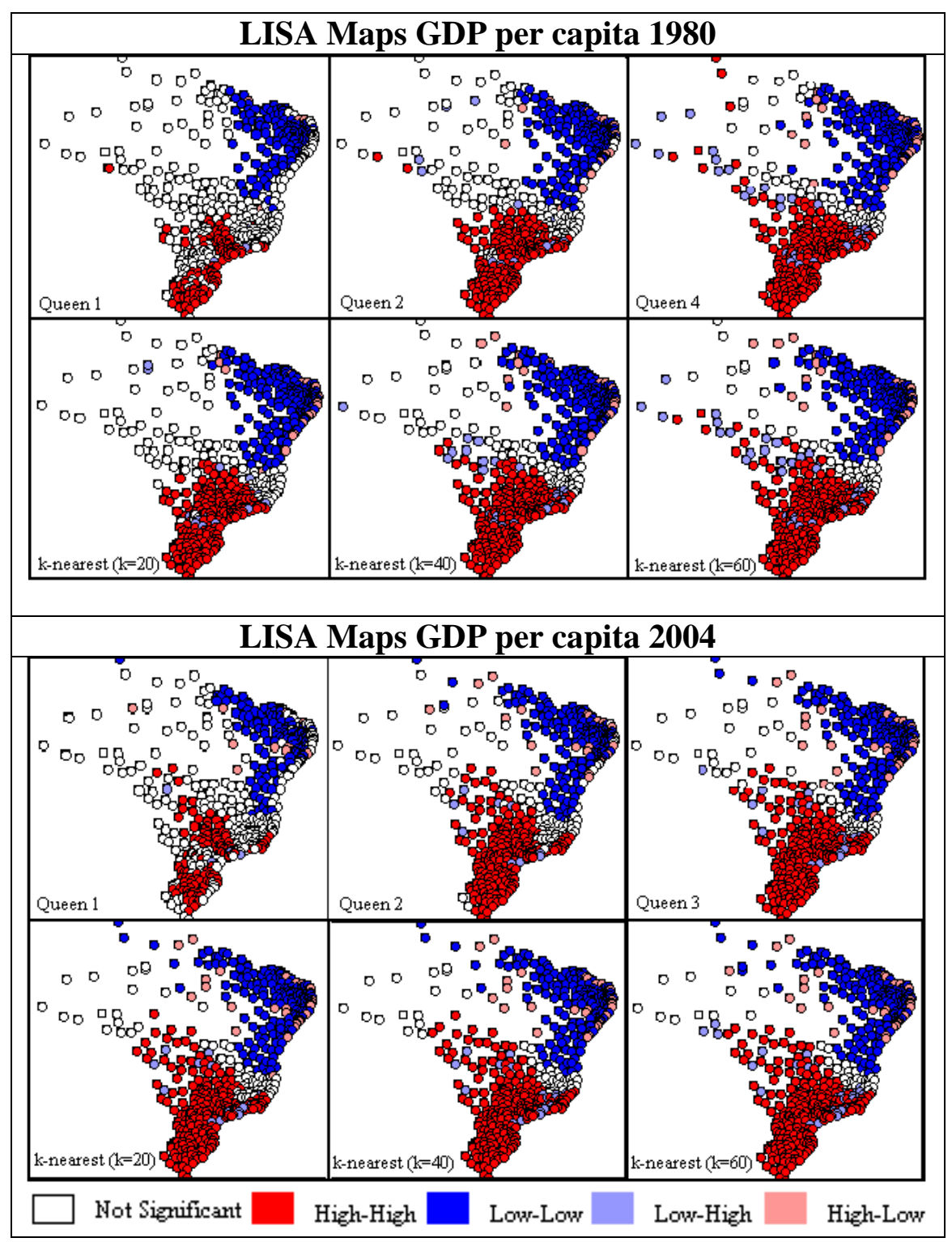

Fig. A.1. LISA Maps for GDP per capita with Alternative Spatial Weights. 
Table 1. Global Spatial Autocorrelation (Moran's I)

\begin{tabular}{|c|c|c|c|c|c|c|}
\hline & $\ln G D P_{t-1}$ & $\ln G D P_{t}$ & $\ln (n+g+d)$ & InSchool & $\ln S M E H$ & $\ln S M E R$ \\
\hline Queen $1^{\text {st }}$ & 0.6773 & 0.6723 & 0.4862 & 0.6270 & 0.3398 & 0.2901 \\
\hline Queen $2^{\text {nd }}$ & 0.6494 & 0.6143 & 0.3929 & 0.6066 & 0.3153 & 0.1925 \\
\hline Queen $3^{\text {nd }}$ & 0.6182 & 0.5642 & 0.3113 & 0.5802 & 0.2883 & 0.1594 \\
\hline Queen $4^{\text {th }}$ & 0.5930 & 0.5315 & 0.2324 & 0.5571 & 0.2582 & 0.1101 \\
\hline$K$-nearest $(k=20)$ & 0.6458 & 0.6143 & 0.3813 & 0.6110 & 0.3464 & 0.1529 \\
\hline$K$-nearest $(k=40)$ & 0.6231 & 0.5732 & 0.3021 & 0.5837 & 0.2991 & 0.1170 \\
\hline$K$-nearest $(k=60)$ & 0.6111 & 0.5553 & 0.2345 & 0.5700 & 0.2798 & 0.0801 \\
\hline Squared Inverse Distance & 0.5680 & 0.5237 & 0.2481 & 0.5258 & 0.2612 & 0.1564 \\
\hline
\end{tabular}

Notes: Results are for the GDP per capita of $1980(t-1)$ and $2004(t)$. The results for the remaining variables are for their average between 1985 and 2004 . The calculations were carried on using the software $\boldsymbol{R}$.

Table 2. Regional Growth in Brazil (508 micro-regions): Non-Spatial versus Spatial Models

\begin{tabular}{|c|c|c|c|c|}
\hline & $\begin{array}{l}\text { LSDV } \\
\text { (1) }\end{array}$ & $\begin{array}{c}\text { SAR } \\
(2)\end{array}$ & $\begin{array}{c}\text { SEM } \\
\text { (3) }\end{array}$ & $\begin{array}{l}\text { SDM } \\
\text { (4) }\end{array}$ \\
\hline $\operatorname{lnGDP}_{\mathrm{t}-1}$ & $\begin{array}{r}-0.1425 * * * \\
(-31.7675)\end{array}$ & $\begin{array}{r}-0.1343 * * * \\
(-24.5779)\end{array}$ & $\begin{array}{r}-0.1478 * * * \\
(-33.2429)\end{array}$ & $\begin{array}{r}-0.1499 * * * \\
(-33.8944)\end{array}$ \\
\hline $\ln (n+d+g)$ & $\begin{array}{r}-0.0082 \\
(-1.0212)\end{array}$ & $\begin{array}{r}-0.0050 \\
(-0.6507)\end{array}$ & $\begin{array}{r}-0.0063 \\
(0.8137)\end{array}$ & $\begin{array}{r}-0.0071 \\
(-0.9070)\end{array}$ \\
\hline $\ln S C H O O L$ & $\begin{array}{r}0.0534 * * * \\
(4.5169)\end{array}$ & $\begin{array}{r}0.0530 * * * \\
(4.6929)\end{array}$ & $\begin{array}{r}0.1067 * * * \\
(6.6326)\end{array}$ & $\begin{array}{r}0.1229 * * * \\
(7.6101)\end{array}$ \\
\hline $\ln S M E R$ & $\begin{array}{r}-0.0090 * * * \\
(-2.8321)\end{array}$ & $\begin{array}{r}-0.0088 * * * \\
(-2.8947)\end{array}$ & $\begin{array}{r}-0.0109 * * * \\
(-3.6697)\end{array}$ & $\begin{array}{r}-0.0114 * * * * \\
(-3.8737)\end{array}$ \\
\hline $\ln S M E H$ & $\begin{array}{r}0.0186 * * * \\
(2.9929)\end{array}$ & $\begin{array}{r}0.0183 * * * \\
(3.0941)\end{array}$ & $\begin{array}{r}0.0211 * * * \\
(3.6716)\end{array}$ & $\begin{array}{r}0.0213 * * * \\
(3.7040)\end{array}$ \\
\hline $\mathrm{W}^{*} \ln \mathrm{GDP}_{\mathrm{t}-1}$ & & & & $\begin{array}{r}0.1545 * * * \\
(9.5253)\end{array}$ \\
\hline $\mathrm{W}^{*} \ln (n+d+g)$ & & & & $\begin{array}{r}-0.0269 \\
(-0.8211)\end{array}$ \\
\hline $\mathrm{W}^{*} \ln S C H O O L$ & & & & $\begin{array}{r}-0.1431 * * * \\
(-5.1530)\end{array}$ \\
\hline $\mathrm{W}^{*} \ln S M E R$ & & & & $\begin{array}{r}0.0276 * * \\
(2.3739)\end{array}$ \\
\hline $\mathrm{W}^{*} \ln S M E H$ & & & & $\begin{array}{r}-0.0301 \\
(-1.2695)\end{array}$ \\
\hline$\rho(\mathrm{SAR}) / \lambda(\mathrm{SEM})$ & & $\begin{array}{r}0.5690 * * \\
(2.3817)\end{array}$ & $\begin{array}{r}0.7940 * * * \\
(10.4037)\end{array}$ & $\begin{array}{r}0.7740 * * * \\
(19.1034)\end{array}$ \\
\hline Observations & 2032 & 2032 & 2032 & 2032 \\
\hline Log likelihood (LIK) & 3387.60 & 3461.7323 & 3510.8821 & 3519.7317 \\
\hline LM & $335.6792(0.0000)$ & & & \\
\hline LMRERR $_{\text {ERR }}$ & $134.5770(0.0000)$ & & & \\
\hline $\mathrm{LM}_{\mathrm{LAG}}$ & $206.3683(0.0000)$ & & & \\
\hline $\mathrm{LMR}_{\mathrm{LAG}}$ & $5.2661(0.0220)$ & & & \\
\hline $\mathrm{LR}_{\mathrm{FE}}$ & & $1168.89(0.0000)$ & $1152.90(0.0000)$ & $1157.63(0.0000)$ \\
\hline
\end{tabular}

Note: $*$ p-value $<0.10, * *$ p-value $<0.05, * * *$ p-value $<0.01$. The results for panel data are based on ELHORST (2010) and associated codes for Matlab available at <www.regroningen.nl/elhorst/software.shtml $>$. The LM tests compare the classic OLS regression against the alternative SAR and SEM specifications under the null of no spatial dependence. The likelihood ratio for fixed effects $\left(L R_{\mathrm{FE}}\right)$ tests for the existence of spatial specific effect against the specification with both, time and spatial fixed effects. The results throughout this section always suggest the consideration of both fixed effects. Numbers in brackets for the coefficients are the $t$-statistics and for the diagnostic tests are the levels of significance. 
Table 3. Panel Results for the Two Regional Regimes

\begin{tabular}{|c|c|c|c|c|c|c|}
\hline & $\begin{array}{c}\text { (1) } \\
\text { SEM } \\
\text { Northern } \\
\end{array}$ & $\begin{array}{c}(2) \\
\text { SAR } \\
\text { Northern }\end{array}$ & $\begin{array}{c}\text { (3) } \\
\text { SDM } \\
\text { Northern }\end{array}$ & $\begin{array}{c}\text { (4) } \\
\text { SEM } \\
\text { Southern }\end{array}$ & $\begin{array}{c}\text { (5) } \\
\text { SAR } \\
\text { Southern } \\
\end{array}$ & $\begin{array}{c}\text { (6) } \\
\text { SDM } \\
\text { Southern } \\
\end{array}$ \\
\hline $\operatorname{lnGDP}_{\mathrm{t}-1}$ & $\begin{array}{r}-0.1443 * * * \\
(-21.0625)\end{array}$ & $\begin{array}{r}-0.1353 * * * \\
(-19.7972)\end{array}$ & $\begin{array}{r}-0.1485 * * * \\
(-21.3746)\end{array}$ & $\begin{array}{r}-0.1521 * * * \\
(-26.7485)\end{array}$ & $\begin{array}{r}-0.1383 * * * \\
(-24.2044)\end{array}$ & $\begin{array}{r}-0.1540 * * * \\
(-26.9650)\end{array}$ \\
\hline $\ln S C H O O L$ & $\begin{array}{r}0.0967 * * * \\
(4.9143)\end{array}$ & $\begin{array}{r}0.1004 * * * \\
(5.1885)\end{array}$ & $\begin{array}{r}0.0963 * * * \\
(4.7740)\end{array}$ & $\begin{array}{r}0.1636 * * * \\
(6.4229)\end{array}$ & $\begin{array}{r}0.1036^{* * * *} \\
(4.8533)\end{array}$ & $\begin{array}{r}0.1804 * * * \\
(6.5502)\end{array}$ \\
\hline $\ln (n+d+g)$ & $\begin{array}{r}-0.0061 \\
(-0.6463)\end{array}$ & $\begin{array}{r}-0.0093 \\
(-0.9990)\end{array}$ & $\begin{array}{r}-0.0019 \\
(-0.2037)\end{array}$ & $\begin{array}{r}-0.0062 \\
(-0.4559)\end{array}$ & $\begin{array}{r}-0.0021 \\
(-0.1546)\end{array}$ & $\begin{array}{r}-0.0082 \\
(-0.5792)\end{array}$ \\
\hline $\ln S M E R$ & $\begin{array}{l}-0.0072 * \\
(-1.8327)\end{array}$ & $\begin{array}{r}-0.0036 \\
(-0.9002)\end{array}$ & $\begin{array}{l}-0.0075^{*} \\
(-1.8848)\end{array}$ & $\begin{array}{r}-0.0150 * * * * \\
(-3.3134)\end{array}$ & $\begin{array}{r}-0.0148 * * * \\
(-3.1839)\end{array}$ & $\begin{array}{r}-0.0151 * * * \\
(-3.3026)\end{array}$ \\
\hline $\ln S M E H$ & $\begin{array}{r}0.0220 * * * \\
(3.4082)\end{array}$ & $\begin{array}{r}0.0209 * * * \\
(3.1739)\end{array}$ & $\begin{array}{r}0.0210^{* * * *} \\
(3.2643)\end{array}$ & $\begin{array}{r}0.0167 \\
(1.1525)\end{array}$ & $\begin{array}{r}0.0192 \\
(1.3314)\end{array}$ & $\begin{array}{r}0.0160 \\
(1.1041)\end{array}$ \\
\hline $\mathrm{W}^{*} \ln \operatorname{lnDP}_{\mathrm{t}-1}$ & & & $\begin{array}{r}0.1045^{* * * *} \\
(4.7162)\end{array}$ & & & $\begin{array}{r}0.1865 * * * \\
(8.4187)\end{array}$ \\
\hline $\mathrm{W}^{*} \ln S C H O O L$ & & & $\begin{array}{r}-0.0007 \\
(-0.0118)\end{array}$ & & & $\begin{array}{r}-0.2396 * * * \\
(-3.9347)\end{array}$ \\
\hline $\mathrm{W}^{*} \ln (n+d+g)$ & & & $\begin{array}{l}-0.0569 * \\
(-1.7537)\end{array}$ & & & $\begin{array}{r}0.0038 \\
(0.0650)\end{array}$ \\
\hline $\mathrm{W}^{*} \ln S M E R$ & & & $\begin{array}{r}0.0400 * * * \\
(2.7966)\end{array}$ & & & $\begin{array}{r}0.0226 \\
(1.1208)\end{array}$ \\
\hline $\mathrm{W}^{*} \ln S M E H$ & & & $\begin{array}{r}-0.0340 \\
(-1.3342)\end{array}$ & & & $\begin{array}{r}0.0310 \\
(0.5277)\end{array}$ \\
\hline$\lambda(\mathrm{SEM}) / \rho(\mathrm{SAR})$ & $\begin{array}{r}0.5230 * * * \\
(7.8880)\end{array}$ & $\begin{array}{r}0.3320 * * * \\
(5.1407)\end{array}$ & $\begin{array}{r}0.4950^{* * * *} \\
(7.3868)\end{array}$ & $\begin{array}{r}0.8579 * * * \\
(23.6393)\end{array}$ & $\begin{array}{r}0.6930 * * * \\
(14.2021)\end{array}$ & $\begin{array}{r}0.8480 * * * \\
(23.7923)\end{array}$ \\
\hline log-likelihood (LIK) & 1411.4709 & 1400.5040 & 1418.6311 & 2122.8757 & 2089.9441 & 2127.2736 \\
\hline Observations & 828 & 828 & 828 & 1204 & 1204 & 1204 \\
\hline $\begin{array}{l}\mathrm{LR}_{\mathrm{FE}} \\
\text { p-value }\end{array}$ & $\begin{array}{r}490.1073 \\
(0.0000)\end{array}$ & $\begin{array}{r}481.3675 \\
(0.0000)\end{array}$ & $\begin{array}{r}496.7470 \\
(0.0000)\end{array}$ & $\begin{array}{r}686.2501 \\
(0.0000)\end{array}$ & $\begin{array}{r}655.2885 \\
(0.0000)\end{array}$ & $\begin{array}{r}691.1910 \\
(0.0000)\end{array}$ \\
\hline
\end{tabular}


Table A.1. Educational Range and Years of Schooling

\begin{tabular}{lr}
\hline RAIS Educational Range Level & Imputed years of Schooling \\
\hline Illiterate & 0 \\
Primary School Dropout & 1 \\
Primary School Graduate & 4 \\
Middle School Dropout & 5 \\
Middle School Graduate & 8 \\
High School Dropout & 9 \\
High School Graduate & 11 \\
College Dropout & 12 \\
College Graduate & 15 \\
\hline
\end{tabular}

Table A.2 Correlations

\begin{tabular}{|c|c|c|c|c|c|c|c|c|c|c|c|c|}
\hline & 1 & 2 & 3 & 4 & 5 & 6 & 7 & 8 & 9 & 10 & 11 & 12 \\
\hline $1 G D P$ growth & 1.00 & & & & & & & & & & & \\
\hline 2 GDP growth*W & 0.57 & 1.00 & & & & & & & & & & \\
\hline $3 \ln G D P_{t-1}$ & -0.27 & -0.23 & 1.00 & & & & & & & & & \\
\hline $4 \ln S c h o o l$ & -0.05 & -0.05 & 0.72 & 1.00 & & & & & & & & \\
\hline $5 \ln (n+g+d)$ & -0.09 & -0.02 & 0.23 & 0.14 & 1.00 & & & & & & & \\
\hline $6 \operatorname{lnSMER}$ & 0.01 & 0.04 & -0.20 & -0.06 & -0.06 & 1.00 & & & & & & \\
\hline $7 \ln S M E H$ & 0.02 & 0.01 & 0.41 & 0.71 & -0.06 & -0.02 & 1.00 & & & & & \\
\hline $8 \ln G D P_{t-1} * W$ & -0.16 & -0.31 & 0.80 & 0.65 & 0.06 & -0.06 & 0.38 & 1.00 & & & & \\
\hline $9 \operatorname{lnSchool} * \mathbf{W}$ & -0.01 & -0.07 & 0.58 & 0.85 & -0.01 & 0.00 & 0.65 & 0.74 & 1.00 & & & \\
\hline $10 \ln (n+g+d)^{*} \mathrm{~W}$ & 0.00 & 0.05 & 0.12 & 0.01 & 0.57 & -0.06 & -0.15 & 0.10 & -0.01 & 1.00 & & \\
\hline $11 \ln S M E R^{*} \mathrm{~W}$ & 0.06 & 0.08 & -0.07 & 0.09 & -0.05 & 0.37 & 0.11 & -0.03 & 0.18 & -0.09 & 1.00 & \\
\hline $12 \ln S M E H^{*} \mathrm{~W}$ & 0.03 & 0.01 & 0.38 & 0.75 & -0.09 & 0.02 & 0.70 & 0.51 & 0.91 & -0.15 & 0.20 & 1.00 \\
\hline
\end{tabular}

Note: The variables followed by $* \mathrm{~W}$ indicate the spatial lag of the respective variable. 
Table A.3. Regional Growth in Brazil (508 micro-regions): Robustness Regressions

\begin{tabular}{|c|c|c|c|c|c|}
\hline & $\begin{array}{l}\text { SDM } \\
\text { (1) }\end{array}$ & $\begin{array}{l}\text { SDM } \\
(2)\end{array}$ & $\begin{array}{c}\text { SDM } \\
\text { (3) }\end{array}$ & $\begin{array}{l}\text { SDM } \\
\text { (4) }\end{array}$ & $\begin{array}{l}\text { SDM - Extended } \\
\text { SME Sector (5) }\end{array}$ \\
\hline $\operatorname{lnGDP}{ }_{t-1}$ & $\begin{array}{r}-0.1482 * * * \\
(-33.37)\end{array}$ & $\begin{array}{r}-0.1498 * * * \\
(-33.8490)\end{array}$ & $\begin{array}{r}-0.1458 * * * \\
(-32.5719)\end{array}$ & $\begin{array}{r}-0.1497 * * * \\
(-33.7472)\end{array}$ & $\begin{array}{r}-0.1508 * * * \\
(-33.9667)\end{array}$ \\
\hline $\ln (n+d+g)$ & $\begin{array}{r}-0.0034 \\
(-0.4363)\end{array}$ & $\begin{array}{r}-0.0072 \\
(-0.9220)\end{array}$ & $\begin{array}{r}-0.0002 \\
(-0.0253)\end{array}$ & $\begin{array}{r}-0.0073 \\
(-0.9273)\end{array}$ & $\begin{array}{r}-0.0088 \\
(-1.1178)\end{array}$ \\
\hline $\ln S C H O O L$ & $\begin{array}{r}0.0717 * * * \\
(5.5927)\end{array}$ & $\begin{array}{r}0.1227 * * * \\
(7.5958)\end{array}$ & & $\begin{array}{r}0.1303 * * * \\
(8.1088)\end{array}$ & $\begin{array}{r}0.1218 * * * \\
(7.6111)\end{array}$ \\
\hline $\ln S M E R$ & $\begin{array}{r}-0.0110 * * * \\
(-3.6944)\end{array}$ & $\begin{array}{r}-0.0114 * * * \\
(-3.8731)\end{array}$ & $\begin{array}{r}-0.0119 * * * \\
(-3.9582)\end{array}$ & $\begin{array}{r}-0.01135 * * * \\
(-3.8211)\end{array}$ & $\begin{array}{r}-0.0307 * * * \\
(-5.7963)\end{array}$ \\
\hline $\ln S M E H$ & $\begin{array}{r}0.0213 * * * \\
(3.6903)\end{array}$ & $\begin{array}{r}0.0204 * * * \\
(3.5757)\end{array}$ & $\begin{array}{r}0.0267 * * * \\
(4.6168)\end{array}$ & & $\begin{array}{r}0.0100 \\
(0.7321)\end{array}$ \\
\hline $\mathrm{W}^{*} \ln \mathrm{GDP}_{\mathrm{t}-1}$ & $\begin{array}{r}0.1443 * * * \\
(8.9086)\end{array}$ & $\begin{array}{r}0.1538 * * * \\
(9.4767)\end{array}$ & $\begin{array}{r}0.1512 * * * \\
(6.4483)\end{array}$ & $\begin{array}{r}0.1551 * * * \\
(9.5472)\end{array}$ & $\begin{array}{r}0.1552 * * * \\
(9.5559)\end{array}$ \\
\hline $\mathrm{W}^{*} \ln (n+d+g)$ & $\begin{array}{l}-0.02967 \\
(-0.9001)\end{array}$ & $\begin{array}{r}-0.0261 \\
(-0.7986)\end{array}$ & $\begin{array}{l}-0.0552 * \\
(-1.6662)\end{array}$ & $\begin{array}{r}-0.0281 \\
(-0.8577)\end{array}$ & $\begin{array}{r}-0.0283 \\
(-0.8523)\end{array}$ \\
\hline $\mathrm{W}^{*} \ln S C H O O L$ & & $\begin{array}{r}-0.1611 * * * \\
(-6.7557)\end{array}$ & $\begin{array}{r}-0.0129 \\
(-0.5804)\end{array}$ & $\begin{array}{r}-0.1434 * * * \\
(-5.1498)\end{array}$ & $\begin{array}{r}-0.1548 * * * \\
(-6.2465)\end{array}$ \\
\hline $\mathrm{W}^{*} \ln S M E R$ & $\begin{array}{r}0.02803 * * \\
(2.3941)\end{array}$ & $\begin{array}{r}0.02649 * * \\
(2.2833)\end{array}$ & $\begin{array}{r}0.0165 \\
(1.4134)\end{array}$ & $\begin{array}{r}0.0277 * * \\
(2.3770)\end{array}$ & $\begin{array}{r}0.0393 * * * \\
(1.8391)\end{array}$ \\
\hline $\mathrm{W}^{*} \ln S M E H$ & $\begin{array}{r}-0.0930 * * * \\
(-4.53278)\end{array}$ & & $\begin{array}{r}-0.0286 \\
(-1.1846)\end{array}$ & $\begin{array}{l}-0.01975 \\
(-0.8353)\end{array}$ & $\begin{array}{r}-0.0619 \\
(-1.2226)\end{array}$ \\
\hline$\rho(\mathrm{SDM})$ & $\begin{array}{r}0.7689 * * * \\
(18.897) \\
\end{array}$ & $\begin{array}{r}0.7699 * * * \\
(18.9622) \\
\end{array}$ & $\begin{array}{r}0.7649 * * * \\
(7.2015) \\
\end{array}$ & $\begin{array}{r}0.7789 * * * \\
(19.2838)\end{array}$ & $\begin{array}{r}0.7710 * * * \\
(18.9639)\end{array}$ \\
\hline $\begin{array}{l}\text { Observations } \\
\text { Log likelihood (LIK) }\end{array}$ & $\begin{array}{r}2032 \\
3506.5769\end{array}$ & $\begin{array}{r}2032 \\
3518.9387\end{array}$ & $\begin{array}{r}2032 \\
3491.2473\end{array}$ & $\begin{array}{r}2032 \\
3512.8741\end{array}$ & $\begin{array}{r}2032 \\
3522.0163\end{array}$ \\
\hline
\end{tabular}

Note: * p-value $<0.10, \quad * * \mathrm{p}$-value $<0.05, * * * \mathrm{p}$-value $<0.01$. The likelihood ratio for fixed effects $\left(\mathrm{LR}_{\mathrm{FE}}\right)$ tests for the existence of spatial specific effect against the specification with both, time and spatial fixed effects. The results throughout this section always suggest the consideration of both fixed effects. Numbers in brackets for the coefficients are the $t$-statistics and for the diagnostic tests are the levels of significance. 
Table A.4. Alternative Regional Results for the SDM Model

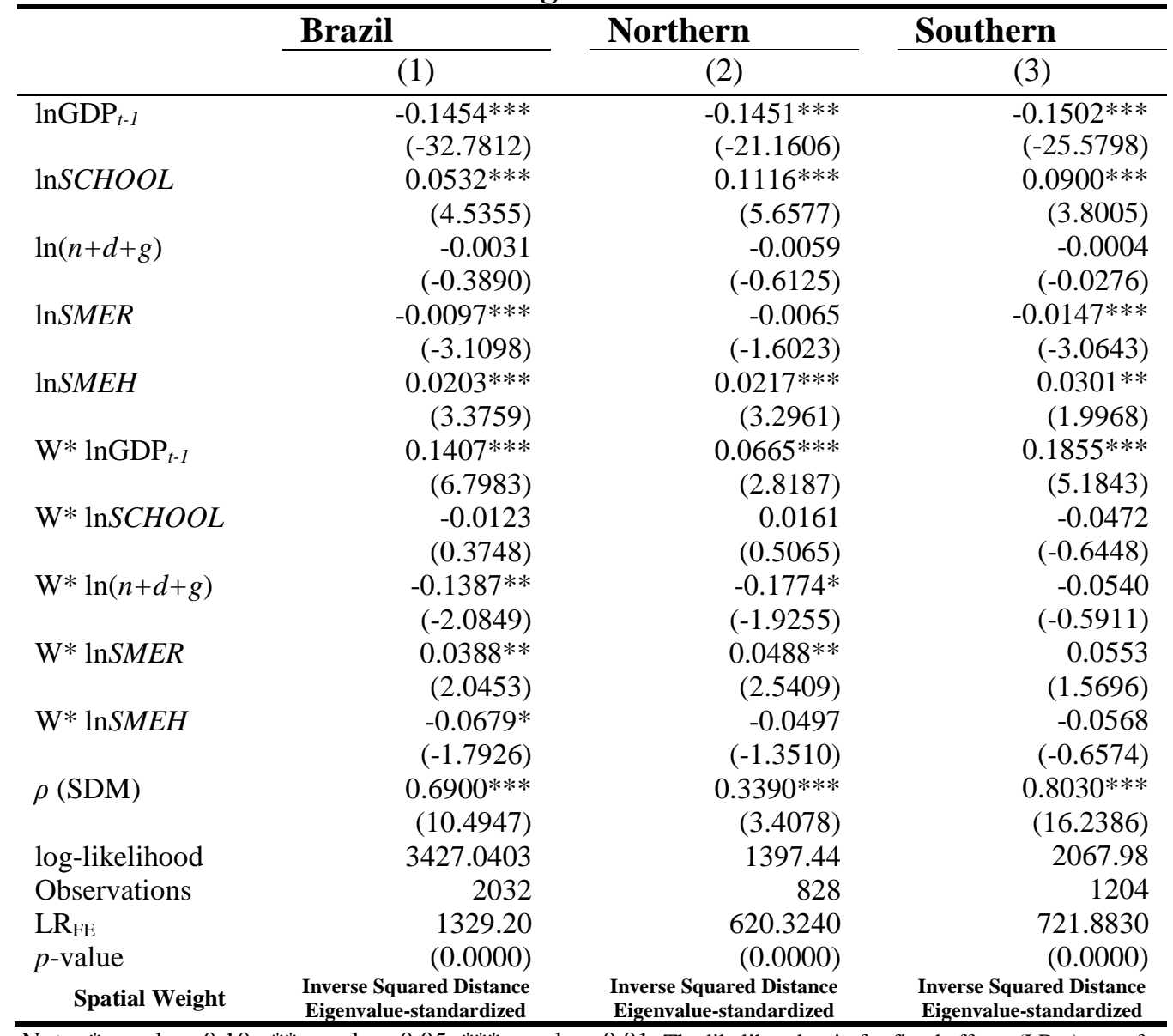

Note: $*$ p-value $<0.10, * * \mathrm{p}$-value $<0.05, * * * \mathrm{p}$-value $<0.01$. The likelihood ratio for fixed effects $\left(\mathrm{LR}_{\mathrm{FE}}\right)$ tests for the existence of spatial specific effect against the specification with both, time and spatial fixed effects. Numbers in brackets for the coefficients are the $t$-statistics and for the diagnostic tests are the levels of significance. 
Table A.5. Alternative Regional Results

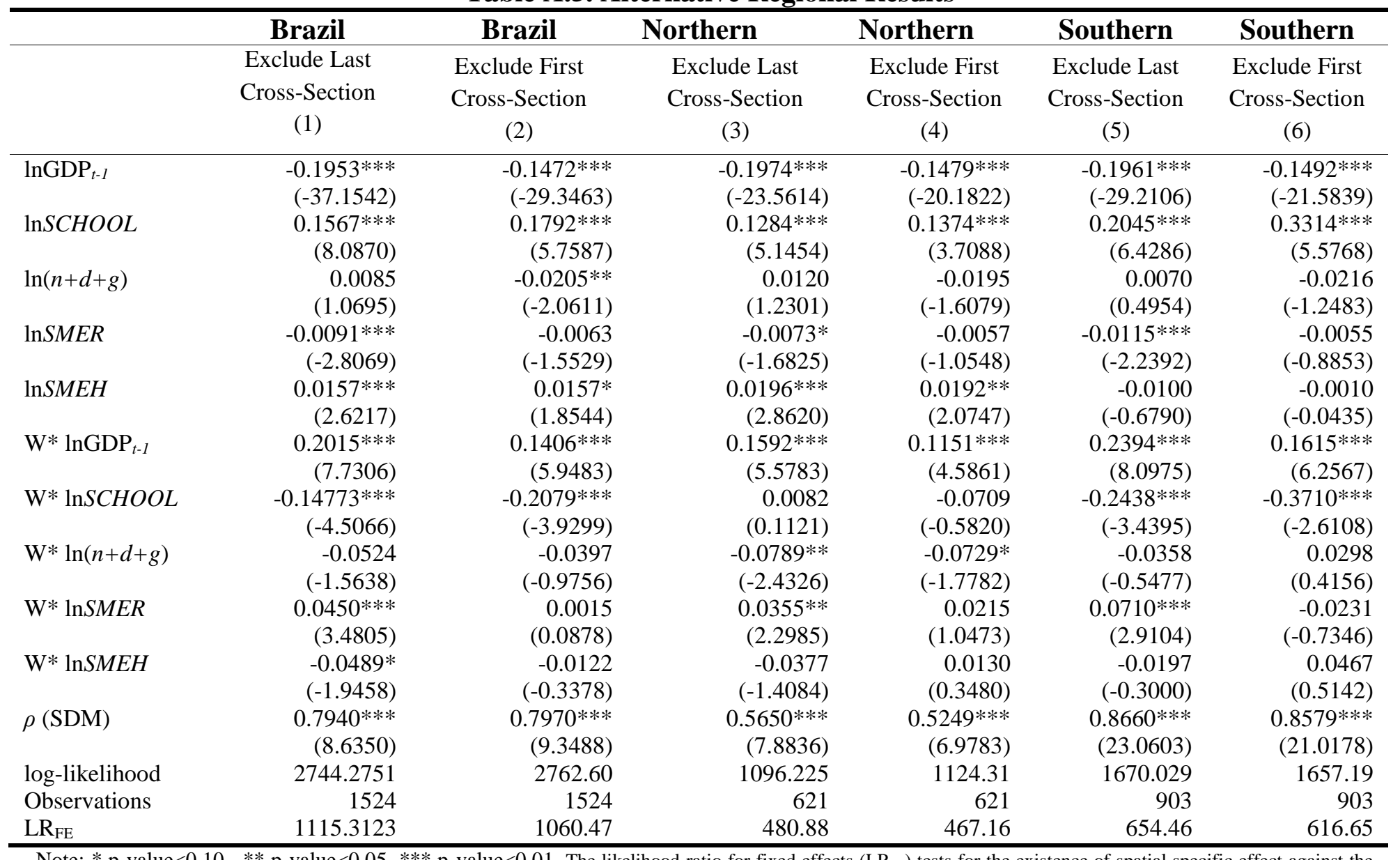

Note: $* \mathrm{p}$-value $<0.10, * * \mathrm{p}$-value $<0.05, * * * \mathrm{p}$-value $<0.01$. The likelihood ratio for fixed effects $\left(\mathrm{LR}_{\mathrm{FE}}\right)$ tests for the existence of spatial specific effect against the specification with both, time and spatial fixed effects. Numbers in brackets for the coefficients are the $t$-statistics and for the diagnostic tests are the levels of significance. All regressions use the inverse squared distance as a spatial weight..The regressions excluding the last cross-section do not use data from 2004 and regressions excluding the first cross-section do not use data from 1985. 